\title{
O CONTROLE JURÍDICO DE POLÍTICAS PÚBLICAS
}

\author{
(Fundamentos Metódico-Estruturantes de uma Proposta de Reforma do Poder \\ Judiciário como Condição Essencial para a Efetivação dos Direitos Sociais, \\ Econômicos e Culturais no Brasil.)
}

\author{
João Paulo Bachur' \\ Aluno do Curso de Graduação da Faculdade de Direito da \\ Universidade de São Paulo
}

\begin{abstract}
Resumo:
O presente trabalho busca apresentar hipótese de reforma do Poder Judiciário brasileiro para efetivar os direitos sociais no Brasil baseada em uma justificação metodológica. Para cumprir esse objetivo, é necessário analisar a origem de tais direitos sociais, bem como à evolução da metodologia científica do Direito. A seguir, é feita proposta de reforma do Poder Judiciário com base em sua justificação metodológica (a metódica estruturante do Direito). Finalmente, as principais objeções são combatidas e algumas conclusões são apresentadas.
\end{abstract}

\begin{abstract}
:
This paper intends to present a hypothesis of reformulation of Brazilian Justice in order to make effective social rights in Brazil based upon a methodological justification. In order to accomplish this aim, is necessary to analyze the origin of such social rights, as well as the evolution of scientific legal methodology. Then, the hypothesis of Brazilian Justice reformulation is made based on his methodological justification (the structuring methodic of Law). Finally, the main objections are faced and some conclusions are presented.
\end{abstract}

Unitermos: políticas públicas; direitos sociais, econômicos e culturais; metodologia da Ciência do Direito; metódica estruturante; reforma do Poder Judiciário.

\section{Introdução e Pré-Compreensão Teórica}

Os direitos sociais são, no mais das vezes, apenados sob a rubrica de "exortações morais" de alta carga retórica. Nada obstante qualquer conotação moral que se lhes queira eventualmente impingir, há que se considerar a necessária eficácia do Direito, sendo essencial a qualquer ordenamento jurídico a produção de seus efeitos

1. Bolsista da Fundação de Amparo à Pesquisa do Estado de São Paulo (FAPESP) cntrc outubro de 1999 c sctembro de 2000, sob a oricntaçào do Prof. Dr. Fernando Haddad 
concretos. E não há como negar o déficit de eficácia prática vivido pelos direitos sociais, pelo menos em nosso País. Ainda, atribuir tal déficit, v.g., à corrupção e à falta de boa vontade política - sem dúvida, fatores constantes das frágeis democracias dos países de capitalismo tardio - não é explicação suficiente. Por óbvio, tais fatores têm de ser considerados, mas há justificativas outras bem mais complexas que simplesmente a vida política e financeira mal organizada das democracias tardias. Há aspectos metodológicos e científicos que influenciam sobremaneira a prática cotidiana desses direitos sociais.

De fato, esta será a perspectiva de estudo adotada: analisar-se-á a ineficácia dos direitos econômicos, sociais e culturais do ponto de vista da metodologia científica do Direito. É fato que os direitos em análise gozam de uma efetividade minimizada, para se não dizer inexpressiva. ${ }^{2}$ Com efeito, o presente estudo é versado preponderantemente em termos de metodologia científica do Direito, na medida em que diante da necessidade de efetivação dos direitos sociais no Brasil se há de indagar pelas vias juridicas adequadas para tanto, bem como pela sua adequada metodologia. Ora, a efetivação dos direitos sociais exige peculiares vias de defesa, as quais devem necessariamente ser fundamentadas, sob pena de incorrerem em um discurso cientificamente inconsistente e panfletário. Enfim, não se pretende qualquer originalidade na proposta aqui apresentada, já outrora defendida por Fábio Konder Comparato, ${ }^{3}$ mas tão somente vislumbrar uma hipótese de aproximação metodológica entre o Poder Judiciário e a implementação de políticas públicas e a efetivação dos direitos sociais, econômicos e culturais.

Antes de iniciar-se a investigação do controle jurídico de políticas públicas propriamente dito, urge fazer alguns esclarecimentos preliminares, em nome da coerência que se pretende dar ao estudo. A expressão "pré-compreensão" adquiriu, ao longo do caminhar da Filosofia, um sentido muito próprio, principalmente após as conquistas da ontologia de Heidegger e da hermenêutica filosófica de Gadamer, ${ }^{4}$ implicando uma profunda modificação nos conceitos de conhecimento e compreensão. Tradicionalmente, sujeito e objeto do conhecimento sempre foram tomados em separado, como compartimentos estanques e independentes. No entanto, ignorar a história e as

2. Conformc o balanço do Instituto Brasilciro de Geografia c Estatística (IBGE) divulgado cm $04 \mathrm{dc}$ abril de 2001, a desigualdade social no Brasil praticamente nada reduziu $\mathrm{cm}$ relação à década de 80 . Apcnas como excmplo ilustrativo, $14 \%$ da renda ficam com os $50 \%$ mais pobre da população, ao passo que $13,1 \%$ da renda ficam com apenas $1 \%$ mais rico da população. Ainda, 13,3\% da população brasilcira é analfabeta (considerando-sc como tais os incapazes de assinar o próprio nome), havendo ainda $29,4 \%$ de anal fabctos funcionais. Por fim, $40,6 \%$ dos domicílios brasilciros não contam com sancamento básico.

3. COMPARATO, Fábio Konder, "Ensaio sobre o Juizo de Constitucionalidade de Políticas Públicas", in Estudos em Homenagem a Geraldo Ataliba, BANDEIRA DE MELLO, Cclso Antônio (org.), São Paulo, Malhciros, 1997.

4. Cf., fundamentalmente, HEIDEGGER, Martin, Ser e Tempo, $2^{4}$ cd., v. I, trad. Márcia de Sá Cavalcanti, Petrópolis, Vozcs, 1988; GADAMER, Hans-Gcorg, Verdade e Método: traços fundamentais de uma hermenêutica filosófica, trad. Flávio Paulo Mcurcr, Pctrópolis, Vozcs, 1997. 
condições que circundam o pesquisador, como se tais fatores não exercessem influência alguma sobre seu conhecimento, é nada menos que uma drástica simplificação da realidade.

Pré-compreensão significa o conjunto de conhecimentos que se possui anteriormente ao conhecimento em si mesmo considerado; é o conjunto de preconceitos do sujeito - preconceitos tomados aqui em sentido absolutamente literal, sem qualquer carga pejorativa, apenas enquanto "pré-conceitos": concepções prévias a toda e qualquer compreensão, compostas por uma tradição cultural e lingüística na qual o sujeito está irremediavelmente inserido, justamente porque ela lhe é historicamente anterior. Mas admitir a pré-compreensão, reconhecer a existência de pré-conceitos, não implica a possibilidade de eliminá-los: os pré-conceitos, enquanto tais, não estão à livre disposição do conhecedor, ${ }^{5}$ não é possível simplesmente distinguir os pré-conceitos que favorecem a compreensão (pré-conceitos produtivos) daqueles que a dificultam (mal-entendidos). No entanto, tal distinção é absolutamente necessária para viabilizar o conhecimento propriamente dito. E a pergunta subseqüente é imediata e inevitável: como separá-los? O distanciamento histórico existente entre o objeto e o sujeito permite formular perguntas, as quais abrem possibilidades de confirmar, negar e/ou substituir os préconceitos por "autêntico" conhecimento - mas que nunca será definitivo, pois sempre provisório e questionável. A partir da pergunta é possivel destacar e avaliar o préconceito, descartando-o e substituindo-o, ou, se for o caso, confirmando-o.

Ao pretender-se a tarefa de estruturar satisfatoriamente um controle jurídico de políticas públicas, está-se, em verdade, assumindo dois pontos de partida (pré-conceitos) que carecem ser identificados: (1) a fronteira entre o jurídico e o político é tênue, havendo uma zona político-jurídica de investigação e atuação; e (2) o Estado Social é um dado seguro da realidade, pois somente faz sentido investigar direitos sociais e políticas públicas no contexto do Welfare State. Esses dois pré-conceitos intrínsecos à investigação proposta precisam ser testados e avaliados, enquanto condicionantes da própria investigação aqui desenvolvida.

As relações entre o Direito e a Política são polarizadas por uma constante tensão que, ao se tratar de temas constitucionais, ganha contornos menos nítidos, em função da característica genérica das constituições do século XX. A constituição que dá forma e vida ao Estado Social é muito diferente daquela que definia os contornos do Estado Liberal. Nesse, a constituição cuidava exatamente de dissociar, da maneira mais precisa possível, o político e o jurídico. Á constituição era apenas a fórmula jurídica de limitação do poder político - um divisor de águas; na medida em que fornecia as bases da organização política com especial atenção aos mecanismos jurídicos de proteção individual contra os excessos do poder político. Daí serem tais constituições conhecidas como "constituições-garantia", ou ainda "constituições-limite", já que sua função precípua era delimitar, juridicamente, uma esfera individual impermeável ao poder político.

5. GADAMER, op. cit., pp. 442/443. 
Diferentemente da pretensa neutralidade constitucional liberal, o Welfare State nunca negou sua orientação axiológica fundamental, qual seja realizar Justiça social a despeito das bases capitalistas que conservou. Naturalmente, essa gênese essencialmente comprometida do ponto de vista político produziu reflexos naquele campo antes reservado exclusivamente ao jurídico. A constituição, de mecanismo de freio do poder político, tornou-se instrumento de coordenação política e planejamento social, sintetizou elementos jurídicos e políticos e introduziu elementos sócio-econômicos ao campo jurídico. O Estado deixou a pura forma jurídica para assumir elementos conceituais substanciais, fundamentalmente os direitos sociais, econômicos e culturais: de fato, o Estado Social constitucionalizou a Política ${ }^{6}$ Portanto, quanto ao primeiro pré-conceito teórico mencionado, é de todo impossivel qualquer negação à fusão conceitual entre a Política e o Direito operada constitucionalmente pelo Welfare State.?

No entanto, esse Estado vem passando, desde há algum tempo e mais precisamente após a segunda metade do século XX, por profunda crise de legitimidade. O modelo do Welfare State foi criado como alternativa aos excessos da pretensamente neutra estrutura liberal-formal burguesa, forçando a estrutura estatal a tomar partido no turbilhão das forças sociais - esse novo paradigma estatal ficou conhecido como democracia social, justamente por tentar difundir determinados padrões de Justiça social, estender a democracia a esferas mais amplas que a participação política exclusivamente. A democracia social é sustentada fundamentalmente pela justificativa ético-política de busca por Justiça social apoiada nas teorias econômicas keynesianas, exigindo compromissos entre a sociedade civil e o poder público, bem como gastos e investimentos para atingir o escopo básico de equacionar os recursos materiais da sociedade mediante a implementação de políticas públicas. Ora, o Estado que destina praticamente toda a receita arrecadada com uma politica fiscal cada vez mais onerosa a amenizar e compensar os impactos sociais gerados nas relações de produção material da sociedade acaba por contrariar o hedonismo do capital em nome de uma opção juridificada - a solidariedade social, que, no entanto, não exige qualquer consenso a respeito. Note-se, então, que em relação aos direitos sociais, a contestação do Welfare State enseja um movimento tendente à sua "desjuridificação."

As jornadas de "juridificação" designam, grosso modo, o processo histórico de crescente promoção dos direitos fundamentais a partir dos séculos XIV e $\mathrm{XV}^{8}{ }^{8}$ De fato, a primeira jornada de juridificação teve lugar no bojo do Estado Absoluto

6. Cf., a respcito, QUEIROZ, Cristina M.M., Os Actos Politicos no Estado de Direito: o problema do controle juridico do poder, Coimbra, Livraria Almedina, 1990.

7. FORSTHOFF, Ernst, "Concetto c Natura dello Stato Sociale di Diritto", in Stato di Diritto in Transformazione, trad. Carlo Amirantc, Milano, Giuffrc̀, 1973, p. 70: "Stato sociale di diritto è una definizione che determina il tipo di un stato, che abraccia costituzione, legislazione ed amministrazione. Esso non è un concetto giuridico". Cf. tambćm QUEIROZ, op. cit., pp. 12 c s..

8. HABERMAS, Jürgen, "Law as Medium and Law as Institution", in TEUBNER, Gunther (org.), Dilemmas of Law in the Welfare State, Berlin/New York, 1985, Europcan University Institutc; HADDAD, Fcrnando, "Economia Politica da Desjuridificação", manuscrito não publicado c fornccido pclo autor. 
e muito pouco tinha a oferecer ao indivíduo, mantendo-o na condição de súdito. A destruição do Ancien Régime consubstanciou a segunda jornada de juridificação, ao conferir ao indivíduo mecanismos jurídicos de proteção de direitos básicos. A terceira jornada já se alinhava ao liberalismo típico do século XVIII, e representou a cristalização da ordem jurídica burguesa, com a proteção precípua dos direitos individuais. Finalmente, a quarta jornada de juridificação, embasada em reivindicações de Justiça social, ao afirmar e institucionalizar a proteção aos direitos sociais, completava um curso crescente e expansivo de afirmação de direitos ${ }^{9}$, tendo no Estado de Bem-Estar Social um paradigma institucionalizado.

Porém, esse movimento ascendente de juridificação foi interrompido pela crise paradigmática do Welfare State, que compila críticas basicamente de três ordens: (1) o Estado passa a enfrentar um descrédito econômico generalizado em função da postura adotada, pois a promoção de bem-estar social exige gastos públicos que, na grande maioria das vezes, são mais elevados que a receita orçamentária e empregados em mecanismos compensatórios dos riscos sociais; (2) tem-se, então, o questionamento dos fundamentos de tal estrutura estatal, ou seja, o sistema que sacrifica toda a coletividade em nome de uma solidariedade social frágil, inconsistente e sujeita a consecutivos déficits orçamentários, passa a ter sua legitimidade ética e política contestada; e, por fim, (3) culminam tais críticas em um movimento de redução e flexibilização do aparato institucional e jurídico estatal, provocando um refluxo na afirmação de direitos fundamentais, com sensivel redução da malha normativa que sustenta o Estado Social de Direito.

E mais, o questionamento do paradigma estatal não se circunscreve a uma postura "de esquerda" ou "de direita" exclusivamente; ele não se restringe a um debate em termos político-partidários mas, de maneira mais grave, aglutina contestações dos dois lados. De um lado, a esquerda política confronta, no âmbito da reprodução simbólica da sociedade, a "publicização do privado" visto que espaços cada vez maiores foram normatizados, tornando estatal um âmbito tradicionalmente legado à esfera privada do cidadão, caracterizando um "imperialismo regulador do Estado" 10 De outro lado, a direita política questiona, no âmbito da reprodução material da sociedade, a "privatização do público", já que as prestações de bem-estar social são apropriadas apenas por reduzida "clientela."

Destarte, retomando o caráter de pré-compreensão teórica, tem-se que os pré-conceitos necessários ao presente estudo não devem ser tomados sem as devidas ressalvas: enquanto Direito e Política estão em constante e irremediável polarização, o paradigma social de Estado revela-se relativamente instável.

9. HADDAD, "Economia Política da Desjuridificação", op. cit., p. 4: "O importante é perceber que a noção de direito vai se modificando ao longo destes cinco séculos e que o direito torna-se progressivamente mais includente".

10. HADDAD, "Economia Politica da Desjuridificaçào", op. cit., p. 4. 
2. Direitos Sociais, Estado Social de Direito, Políticas Públicas: Enfoque DiacrônicoAnalítico

A a firmação dos direitos sociais, econômicos e culturais tem necessariamente de ser entendida no contexto da marcha histórica dos direitos humanos. Nada obstante o fato de representarem os direitos individuais e políticos as exigências precípuas da sociedade pós-medieval (pré-industrial), há razões adicionais que justificam o diferimento temporal entre sua afirmação e a dos direitos sociais. Para compreender essas razões é necessário recorrer ao conceito de cidadania desenvolvido por T. H. Marshall: " $A$ cidadania é um status concedido àqueles que são membros integrais de uma comunidade" " A cidadania, então, leva em conta a integração do indivíduo, o que permite uma importante consideração: uma vez que o cidadão é indivíduo socialmente participativo e integrado, pode-se mitigar e graduar a cidadania, já que nem todos gozam de igual integração social. Circunstâncias várias quantificam a integração social, o que inevitável e pesarosamente exclui a participação de parcela da população.

Vislumbre-se o conceito de cidadania sob um tríplice enfoque, decomposto que pode ser em três elementos ou partes, a saber, o elemento civil formado pelas garantias e liberdades individuais; o elemento politico representado pelo poder de participação política conferido aos cidadãos; e finalmente o elemento social, consubstanciando as condições necessárias para uma vida minimamente digna. A mitigação do conceito de cidadania é, então, plenamente justificável, já que: "Sua evolução envolveu um processo duplo, de fusão e de separação. A fusão foi geográfica e a separação, funcional" ${ }^{12} \mathrm{O}$ movimento de reunião dos feudos sob autoridade régia financiado pelos burgueses provocou a fusão geográfica dos loci de participação cidadã, antes atomizados na estrutura feudal, o que fez com que o indivíduo deixasse o feudo e passasse a ser súdito nacional. Isso o distanciou, física e geograficamente, das instituições que viabilizavam sua manifestação comunitária, pois o vilarejo havia virado o país, sob as vestes de Estado (Absoluto) nacional. O reflexo instantâneo dessa fusão geográfica foi a separação funcional das instituições que viabilizavam essa participação integradora e garantiam direitos, tais como os órgãos jurídicos, políticos e os prestadores de serviços públicos, redundando na independência das instituições sociais.

Ao desenvolvimento conceitual fragmentado da cidadania, adicione-se a solidificação definitiva da burguesia, enquanto classe social. Era esse o derradeiro passo. Ora, enquanto a cidadania é um conceito expansivo e includente, a classe social é um sistema de desigualdade, restritivo e excludente, pois institucionaliza a desigualdade social como necessidade do sistema - a cidadania significa a homogeneização do status, ao passo que a classe social, ao contrário, fixa uma hierarquia

11. MARShall, T. H., Cidadania, Classe Social e "Status". trad. Mcton Porto Gadella, Rio de Janciro, Zahar Editores, 1967, p. 76.

12. MARSHALL, op. cit., p. 64. 
do status social. ${ }^{13}$ Destarte, é fácil identificar as razões do déficit de eficácia dos direitos sociais, sob um enfoque diacrônico-analítico, considerando-se que o diferimento temporal-conceitual da cidadania fez com que os direitos fossem reconhecidos e afirmados em épocas diferentes: em um primeiro momento, de ruptura com o absolutismo, reconheceram-se apenas os direitos civis e políticos, sendo que, no entanto, nesse mesmo momento houve o empossamento político da burguesia, o que consolidou o capitalismo industrial e seu sistema de classes sociais; e considerando-se, então, a tensão antitética existente entre os conceitos de cidadania e classe social, a expansão da cidadania dependia de um afrouxamento da estrutura capitalista de classes sociais, o que, por sua vez e em função da consolidação de uma ordem social liberal-burguesa, não ocorreu, pois o sistema de classes sociais engessou a expansão da cidadania.

Com efeito, a consolidação da ordem burguesa sublimada pelo paradigma do Estado Liberal produziu, com absoluta coerência, uma estrutura jurídica formal que consubstanciava determinados preceitos vitais para seu crescimento, tais como a liberdade de contratar e a garantia da propriedade privada, sob os auspícios das grandes codificações de Direito Privado e das constituições-limite. Nesta esteira, o Estado se abstinha de participar do jogo de forças da sociedade. Ora, as conseqüências são, quando não-óbvias, ao menos intuitivas: plena liberdade econômica e irrefreado hedonismo industrial-capitalista elevaram-se à máxima potência, radicalizando a exploração do trabalho pelo capital e redundando em aviltante exploração do proletariado que, por sua vez, não tinha a quem recorrer, restando cada vez mais ensimesmado em suas mazelas. ${ }^{14}$

O modelo liberal só foi reformulado após duas Guerras Mundiais e a Grande Depressão, de 1929. As contingências econômicas e sociais intrínsecas ao liberalismo, ao se materializarem em deflagrações militares e crise econômica de proporções globais, deixaram os paises absolutamente atônitos. Após a II Guerra Mundial, adveio um novo modelo - o Welfare State (Estado Democrático Constitucional, Social-Democracia, ou Estado Social de Direito). ${ }^{15}$ Esse modelo de Estado fundou-se numa legitimidade que extrapolou a legalidade, a exigência de Justiça social impôs

\section{MARSHALL, op. cit., p. 76.}

14. Cf. Hobsbawn, Eric J., A Era das Revoluçöes, I0a ed., trad. Maria Tereza Lopes Tcixcira c Marcos Penchel, Rio de Janciro, Paz c Terra, 1977. Quanto à condição de vida dos opcrários, instaurou-sc um mórbido contexto de degradação c desorganização sociais: com a destituição da propriedade opcrada pclos Enclosure Acts britânicos, os camponeses sc rendiam ao trabalho nas fábricas, submetendo-sc a jornadas de trabalho abusivas, extremamente mal remuneradas $\mathrm{e} \mathrm{cm}$ condições absolutamente insalubres de trabalho. O caos social provocou a pcrda dos padrõcs básicos de comportamento, levando também à degradação ćtica c moral da socicdade, cxplodindo os nivcis de alcoolismo, criminalidadc, prostituição c suicidio na socicdade. Como sc não bastassc, a cxpansão urbana completamente desordenada c confusa impedia o accsso de grande parcela da população aos scrviços públicos mais clementares, favorecendo a prolifcração de docnças cpidêmicas cm larga escala. Apcsar de tudo, tal situação nào cra vista, pelo menos a principio, como ilcgítima, mas como um preço a ser pago pela Revolução Industrial.

15. O Estado Social pode assumir tanto a forma totalitária, como ocorrcra na Itália fascista 'e na Alcmanha nazista, quanto a forma democrática. Em repúdio ao totalitarismo, o Estado Social também passou a scr chamado Estado Democrático Constitucional ou ainda Social-Democracia. 
tarefas ao Estado que, de mero observador da sociedade transmudou-se em seu principal transformador, não se legitimando em garantias formais como fizera o Estado Liberal, mas sim em garantias materiais, cujo fator de legitimidade é também material. ${ }^{16}$ Nesse sentido, reportamo-nos novamente ao conceito de cidadania conforme desenvolvido por T. H. Marshall, pois o Estado Social permitiu que o terceiro e final elemento da cidadania fosse finalmente afirmado, retomando em pleno século XX o desenvolvimento da cidadania iniciado no século XVIII. Por tudo isso, a noção de políticas públicas é intrínseca ao contexto social-democrata, devendo ser entendida como o vetor estatal precípuo de distribuição de renda e implementação de direitos sociais, conforme um núcleo conceitual composto por "direitos sociais - Estado Social de Direito - politicas públicas" que não pode ser fragmentado: daí o risco que a crise do Estado Social apresenta para o presente estudo.

3. A Insuficiência Metodológica do Positivismo Jurídico e a Metódica Estruturante do Direito, enquanto Método de Trabalho Jurídico Pós-Positivista

Quando se quer tratar da insuficiência metodológica do positivismo juridico, há primeiro de se conceituar e definir o positivismo jurídico para em seguida qualificá-lo como metodologia e daí então atestar suas falhas. ${ }^{17} \mathrm{O}$ positivismo jurídico pode ser entendido como o resultado obtido na tentativa de adaptação da Ciência do Direito à explosão cientificista que tinha em sua linha de frente a Astronomia, a Física e a Biologia, respectivamente com Kepler, Isaac Newton e Darwin, representando os frutos intelectuais de uma época resultante da fusão do Renascimento italiano do século XV com a Reforma Protestante do século seguinte, sob o impacto da filosofia cartesiana, que moldou a filosofia positiva, cuja maior expressão é Auguste Comte. Em reação frontal à tradicional concepção metafísica que se tinha do conhecimento e da Ciência em geral, emergiu um movimento intelectual novo que só adjetivava de "científico" o conhecimento assentado na certeza, que não mais se satisfazia quer com explicações metafisicas, como haviam pretendido, embora com objetivos diversos, Thomas Hobbes, John Locke e todos os filósofos do iluminismo, quer com a excelência ideal-racional de uma razão apriorística, como quisera Immanuel Kant; mas sim e somente com a possibilidade de demonstração e prova empírica do conhecimento por meio de leis. $\mathrm{O}$

16. A partir da tipologia tríplice de Max Weber para a legitimidade, nota-se que nem a dominaçào tradicional, ncm a dominação carismática, ncm a dominação racional-legal são capazcs de cxplicar a legitimidade do Estado Social; cle transcende os fatores formais de legitimação, pois tem uma justificativa matcrial imanentc, fundada cssencialmentc nos dircitos sociais, cconômicos c culturais. Cf. KRIELE, Martin, Introdución a la Teoria del Estado: fundamentos históricos de la legitimidad del Estado Constitucional Democrático, trad. Eugênio Bulygin, Bucnos Aires, Depalma, 1980.

17. Notc-se que, diferente das rasas c usuais críticas feitas ao positivismo jurídico, não se trata da oportunidade de atacá-lo comparando a "purcza" pretendida à vida cotidiana do Dircito. O cstudo que sc pretende ć outro, fundado nas bases metodológicas c cpistemológicas do positivismo jurídico, ou scja, cm outras palavras, fundado nas condições de conhecimento do Dircito adotadas pelos positivistas. 
conhecimento só podia ser neutro e fundado na observação, não misturando aquele que observa ao observado e, desta sorte, necessariamente relativo. Daí a necessidade de construir-se um conceito de Ciência do Direito adequada aos avanços intelectuais do "espírito positivo" e que, portanto, primasse por um rigor formal que exprimisse a observação do Direito tal como ele efetivamente se nos apresenta, com absoluta neutralidade axiológica, demonstrando o Direito - era necessário conferir maior exatidão e certeza à Jurisprudência. ${ }^{18} \mathrm{O}$ positivismo jurídico nada mais é que o fruto das irradiações desse avanço científico e intelectual do século XVIII no campo da Ciência do Direito, um revide à imortalidade imanente do jusnaturalismo até então reinante, enriquecido pelas influências da escola histórica de Savigny, da genealogia dos conceitos de Puchta e da jurisprudência dos interesses de Jhering.

Portanto, para os fins pretendidos, o juspositivismo deve ser captado globalmente enquanto metodologia científica, i.e., enquanto uma forma particular de apreender a atuação do Direito. Mesmo sob esse ponto de vista, não há, porém, uma forma padrão que o designe, mas diversas facetas aparentemente incompatíveis entre si. ${ }^{19}$ Sob olhar mais acurado, as variadas correntes juspositivistas apresentam

18. Cf. Larenz, Karl, Metodologia da Ciência do Direito, Ga cd., trad. Josć Lamego, Lisboa, Fundaçìo Colouste Gulbenkian, 1997, pp. 46/47: "caracteriza-se [o positivismo] pelo seu empenho em banir loda "metafisica" da ciência e restringir rigorosamente esta última aos "factos" e às leis desses factos. considerados empiricamente. (...) A ciência do Direito será assim erigida em "verdadeira ciência" quando. tal como a ciência da natureza, se fundar sobre factos indubitáveis".

19. Ernst Rudolf Bicrling, c.g., cntende a normatividade como um "querer a norma" individual c psicológico. Eugen Ehrlich, por outro lado, põc todo o foco de cstudo na normatividade sociológica do Dircito, sendo a ordem jurídica clemento social empírico como outro qualquer que não goza de peculiaridade alguma, nem sequer a coação: "Moral, religiāo, costume, boas maneiras, até moda, nūo só ordenam as relaçòes extrajuridlicas, mas influenciam passo a passo, a juridica", c "Desta maneira, o homem age de acordo com o direito, acima de tudo, porque as relaçòes sociais o obrigam a isto!" (Ehrlich, Eugen, Fundamentos de Sociologia do Direito, trad. Renć Ernani Gertz, Brasília, Universidade de Brasília, 1986, pp. 151 c 49, respectivamente). Convergindo o enfoque psicológico c o sociológico, Alf Ross, na vertente conhecida por realismo jurídico (psico-sociologismo), funde na vigência do Dircito os conceitos de validade c cficácia: a ordem jurídica socialmente obrigatória é vista por scus destinatários como vinculante $\mathrm{c}$ imperativa, mesclando aspectos sociológicos $\mathrm{c}$ psicológicos. Hans Kclsen, por outro lado, cm sua busca por uma tcoria pura de contaminações extrajurídicas fez com que o ângulo de observação do Dircito fossc apenas cle mesino: concebendo-o como sistema hermético c estritamente jurídico, todas as normas decorriam umas das outras $\mathrm{cm}$ ordem cscalonada, com fundamento $\mathrm{cm}$ uma norma fundamental. Aliás, a tcoria da Grundnorm chàma a atenção por sua intrínseca tensão inconciliávcl: ao tentar rompcr com todo fundamento não jurídico, derivando as normas umas das outras $\mathrm{cm}$ ordem cscalonada, Kelsen sc vê cncurralado no absurdo de uma regressão ao infinito, faltando-lhc o fundamento jurídico da primcira norma. Destartc, tcm de intcrrompcr a sequücncia, cmbora tal intcrrupçào scja fcita de mancira formal-apriorística (c, portanto, extrajuridica): "Tem de terminar numa norma que se pressupóe como a última e mais elevada. Como norma mais elevada, ela tem de ser pressuposta, visto que nào pode ser posta por uma autoridade, cuja competência teria de se fiundar numa norma ainda mais elevada. A sua validade jä não pode ser derivada de uma norma mais elevada, o fundamento de sua validade jä nào pode ser posto em questäo. Uma tal norma, pressuposta como a mais elevada, será aqui designada como norma firndamental" $(\mathrm{Kclscn}$, Hans, Teoria Pura do Dircito, 6a cd., trad. João Baptista Machado, Coimbra, Armcnio Amado Editora, 1984, p. 269). Outras cscolas positivistas, tais como a analítica de H. L. A. Hart c Norberto Bobbio c o institucionalismo de Ota Weinberger, cm função dos limitcs deste trabalho, não poderào ser cstudadas. 
como traço metodológico constante um necessário corte epistemológico que, em um momento ou outro e sob um ponto de vista ou outro, faz-se imprescindível para fins de simplificação operacional da realidade. Note-se ser essa simplificação da realidade a única maneira de o positivismo jurídico se sustentar e se mostrar coerente e, em alguma medida, trabalhar os dados reais. O necessário corte epistemológico é elemento de unidade e diversidade do juspositivismo, pois permite compreendêlo como metodologia ao mesmo tempo em que permite ver ramos frutuosamente desenvolvidos por uma série de "positivismos" jurídicos que, no entanto, apresentam um necessário "quid" epistemológico comum. Ora, esse corte significa a necessária redução que o Direito deve sofrer para se enquadrar nos anseios de certeza e previsibilidade empírica ditados pela filosofia positiva - ele une as diferentes vertentes positivistas sob teto comum, pois opera a redução unilateral do Direito a apenas um de seus aspectos, exclusivamente, como forma de operacionalidade metodológica.

Com esse artificio metodológico, o formalismo positivista elimina, de começo, o caráter histórico e cultural de toda ordem jurídica, pois busca descrevê-la em termos gerais e a-históricos para fins de conhecimento definitivo. Claramente, é necessário que a Ciência jurídica trabalhe com conceitos genéricos e excessivamente abstratos, o que, além de perder a dimensão cultural do Direito, perde também a sua riqueza empírica. Some-se a isso a impossibilidade de o legislador prever todas as situações possíveis e imagináveis da vida humana. Apesar de todas as negativas dos positivistas, sempre existirão lacunas, que não significam um vácuo jurídico, mas apenas sua inexperiência diante de determinadas situações que não foram, porque não o podiam ser, previstas pelo legislador. No entanto, nestas situações limite, não se esquiva o juiz da decisão do caso concreto, quer dizer, o juiz tem necessariamente de eliminar o conflito, mesmo não reconhecendo a exiștência das lacunas. Dessa forma, à luz do princípio da proibição do "non liquet" o preenchimento de tais lacunas é necessariamente feito pelo juiz, sem qualquer padrão de controle ou de justificativa, o que permite que certas decisões sejam tomadas alheias ao Direito por se fundarem em elementos fáticos exteriores ao ordenamento e, portanto, incontroláveis e muitas vezes mesmo injustificáveis. Como se não fosse suficiente, o positivismo tem dificuldades em reconhecer a carga ambígua e maleável da linguagem, que permite seu uso axiológico. Finalmente, o grande problema continua sendo a incapacidade de o positivismo vedar normas injustas, pois diferindo Direito e Política, aquele só operacionaliza esta, o que faz com que as decisões tomadas no âmbito político não sejam questionadas pela Jurisprudência, tendo de ser por esta colocadas em prática.

Ora, todas estas críticas e falhas detectadas no positivismo jurídico conduzem, com certa perplexidade, a um paradoxo extremamente interessante: a busca incessante de certeza e previsibilidade imposta por um conceito de Ciência positiva traduziu-se, no mais das vezes, em fatores de insegurança, descontrole e até mesmo irracionalidade na praxis da Jurisprudência. Nesse sentido, desnudando o mecanismo 
de estudo e conhecimento próprio do positivismo, já se pode constatar sua inequívoca insuficiência metodológica para tratar o Direito real. ${ }^{20}$

As falhas que o positivismo apresenta em sede de metodologia científica acabaram por induzir sua superação. Como se não bastasse, o advento do Welfare State só fez complicar a situação dos positivistas, que não tinham como se socorrer diante da nova moldura dada ao Direito pelo impacto social. Com o Estado Social, o Direito teve de ser compreendido em sua lógica fundamentalmente material e substancial, abandonando sua tradição formal de há muito arraigada e impregnada no pensamento jurídico. Enquanto no Estado burguês a única preocupação jurídica era resguardar uma esfera de liberdade representada pelos direitos individuais e suficientemente protegida pela regra jurídica, o novo modelo de Estado produz um Direito que sé serve de uma estrutura principiológica e de normas que não podem ser transcritas pela regra singela, mas que demandam crescente valoração e uma atitude construtivista do operador do Direto (são o que tradicionalmente se apelidou de "normas programáticas"), principalmente voltadas para os direitos sociais, econômicos e culturais.

As novas necessidades metodológicas do Direito somente seriam providas pela metódica estruturante (strukturierende Methodik) enquanto método de trabalho jurídico (Recthsarbeit), o que implicou uma atitude deliberada de rompimento com o positivismo. Para tanto, o ponto de partida, de acordo com o principal teórico da metódica estruturante, Friedrich Müller, ${ }^{21}$ é não-identificar a norma a seu texto. Identificando-se o texto à norma, somente resta ao operador do direito verificar se a situação de fato que lhe é submetida se encaixa na prescrição legal, executando um silogismo, através da subsunção formal do fato à norma. De fato, não se identificando a norma ao seu texto oficial, todos os textos comumente chamados de "normativos" carecem de concretização, ao passo que esta, por sua vez, em nome do controle racional de todo o trabalho jurídico, deve se dar de forma metodicamente estruturada. Essa é a tônica da metódica estruturante do Direito: todos os textos de normas têm de ser metódica e estruturadamente concretizados.

A metódica não se pretende nem pura nem universal, embora isso não implique qualquer sinçretismo metodológico. Ela visa apénas ser um método de trabalho suficiente, convergindo diversas fontes de conhecimento. A primeira delas está no desenvolvimento da filosofia ontológica, principalmente em suas raízes desenvolvidas por Hegel e passando notadamente por Heidegger. Para compreender-se a incessante busca da metódica por uma "concretização" do Direito, faz-se imperioso volver ao "conceito concreto" ou "geral-concreto" de Hegel sem, de maneira alguma, equiparar a norma jurídica a ele. Esse conceito concreto é composto por "um todo de "momentos"

20. Cf., CORDEIRO, António Menezes de, "Introduçào à Ediçăo Portuguesa", in CANARIS, ClausWilhclm, Pensamento Sistemático e Conceito de Sistenta na Ciência do Direito, 2a cd., trad. António Menczes de Cordciro, Lisboa, Fundação Calouste Gulbenkian, 1996

21. MÜLLER, Fricdrich, Discours sur la Méthode Juridique, 5a ed., trad. Olivier Jouanjan, Paris, Presses Universitaires de France, 1996. 
relacionados entre si de modo pleno de sentido, que só nesta vinculatividade recíproca constituem o conceito" 22 O conceito é formado a partir da fusão de momentos apreendidos apenas idealmente em sua individualidade, pois só adquirem sentido em sua reciprocidade inexorável. A operação que divide o conceito em momentos, reflete sobre eles e opera sua reconstrução é toda uma operação dialética e ideal - a totalidade do ser enquanto idéia absoluta a si tudo submete. ${ }^{23} \mathrm{E}$ aqui reside o ponto que impede a redução da metódica estruturante do Direito a uma réplica da dialética hegeliana: a metódica é essencial e absolutamente concreta.

A hermenêtica filosófica, por sua vez, notadamente a partir da investigação desenvolvida por Hans-Georg Gadamer, enriquece espantosamente o discurso científico da Jurisprudência, na medida em que não separa, em absoluto, o sujeito que conhece do objeto conhecido, existe um vínculo prévio entre eles: trata-se da pré-compreensão, já uma vez aqui referida, composta pela tradição em que o investigador está irremediavelmente inserido, quer em sua vertente lingüística, quer em sua vertente substancial. ${ }^{24}$ A interpretação clássica, tradicionalmente divida em subtilitas intelligendi (compreensão), subtillitas explicandi (interpretação) e subtillitas aplicandi (aplicação), fora totalmente subvertida pela hermenêutica filosófica, pois era "um processo unitário não somente a compreensão e interpretação, mas também a aplicação"2s , sendo tal processo unitário operado sob a forma do círculo hermenêutico.

Um terceiro elemento substancial na formação da metódica estruturante é de caráter essencialmente argumentativo e remonta à tópica a Aristóteles, sucessivamente resgatada por Cícero e Gian Batista Vico, mas somente reconhecida na Ciência do Direito a partir de Theodor Viehweg ${ }^{26}$. A tópica é a argumentação por meio de "topoi", lugares-comuns argumentativos que desempenham importante papel

22. LARENZ, op. cit., p. 652.

23. HEGEL, Gcorg Wilhelm Fricdrich, Enciclopédia das Ciências Filosóficas em Epitome, v. 1, trad. Artur Morão, Lisboa, Edições 70, 1988, § 213, p. 209: “A idéia é o verdadeiro em si e para si, a unidade absoluta do conceito e da objectividade". A metódica cstruturante usa fatos para fixar a norma jurídica que realmente toma a forma de uma decisão concreta, bem distante de qualquer idcalização. Os conceitos, pensados c dissociados de antemão, ao unirem-sc, constitucm o conccito $\mathrm{cm}$ um movimento de duplo sentido, semelhantc ao conhecido "circulo hermencutico"

24. Com efcito, Heidegger já havia identificado um momento prévio ao conlıccimento, bem como já havia considerado, outrossim, comprecnsão $\mathrm{c}$ interpretação como momentos unitários (Heidegger, op. cit., p. 204).

25. Gadamcr, op. cit., p. 460. Ainda, corroborando a íntima ligação entre a hermençutica filosófica c a ontologia hegcliana, cf. p. 451: "A partir disso a tarefa da hermenêtutica filosófica pode ser caracterizada como segue: tem de refazer o caminho da fenoménologia do espirito hegeliana, até o ponto em que. em toda subjetividade, se mostra a substancialidade que a determina". Dai a ligação cntrc a ontologia, a herınenêutica filosófica c a metódica cstruturante do Dircito, vez que a concretização demanda a junção de momentos (âmbito c programa da norma, como sc verá), muito embora a norma jurídica somente possa scr cxtraída a partir desse processo dialético c referida ao caso, somente assumindo algum sentido $\mathrm{cm}$ sua concretude.

26. Vichwcg, Theodor, Tópica e Jurisprudência, 5a cd., trad. Tércio Sampaio Fcrraz Jr., Brasilia, Universidade de Brasília c Ministério da Justiça (co-cdição), 1979. Em verdade, a tópica nunca se pretendeu 
na solução de questões jurídicas, tais como, e.g., a "boa-fé" Cada "topos" pode ser utilizado conforme o caso que se quer decidir, e seu significado é elástico, sendo essencialmente definido em função do caso. A tópica enfatiza essencialmente o problema, e é a partir dele que um arcabouço argumentativo é desenvolvido para a resolução do caso concreto, funcionando, assim, a partir de "panoramas fragmentários": premissas escolhidas sem qualquer sistematização, através de tentativas de solução e que compõem o quadro argumentativo jurídico. Essas tentativas tornam-se premissas quando aceitas como razoáveis pelo senso comum no discurso jurídico ${ }^{27}$. Dessa forma, as decisões não são obtidas como uma decorrência da ordem positiva, mas sim como um processo de contraposição de argumentos aceitáveis, dentre os quais um é o melhor para decidir o problema.

Não-obstante todas as críticas que lhe podem ser dirigidas ${ }^{28}$ e muito embora pensamento sistemático e tópica sejam apresentados como antíteses recíprocas, o antagonismo entre eles é menos real que aparente, havendo mais propriamente uma verdadeira complementaridade entre sistema e tópica - e, de fato, foi na medida dessa complementaridade que ambos foram incorporados pela metódica. No entanto, não se trata do sistema lógico-formal de há muito abandonado pela Jurisprudência, sendo-lhe adequado apenas o conceito de sistema aberto conforme desenvolvido por Canaris. Com efeito, o sistema aberto, além de permeável a valorações, comporta a problematização, embora de forma ampliada e genérica, pois algumas questões não são tratadas como problemas, sendo desde já oferecidas determinadas respostas aos problemas mais gerais. Destarte, relega o pensamento sistemático uma posição secundária ao pensamento tópico, destinado fundamentalmente a complementar os pormenores inatingiveis pela generalidade sistêmica. ${ }^{29}$

científica no sentido apodítico do termo, assumindo-se sempre como estilo problemático de raciocinio, sendo cxatamente por isso e nesse ponto substancialmente criticada. Cabe obscrvar, de fato, que tal enfoque problemático cra a base mesma do Dircito Romano, cssencialmente pragmático e sempre voltado para um problcma a ser rcsolvido, clamado cntrc os romanos de "prudência" (Cf. Ferraz JR., Tércio Sampaio, Introduçũo ao Estudo do Direito, 2a cd., São Paulo, Atlas, 1994, pp. 56 c s., especialmente p. 58: "O pensamento prudencial desenvolvido nos responsas dos jurisconsultos romanos tinha algo de semelhante às técnicas dialéticas dos gregos"). E foi cxatamente nesse sentido de prudência c dialćtica que a tópica foi retomada por Vichweg.

27. ARISTÓTELES, op. cit., livro I, I, p. 5, definc as premissas accitas $\mathrm{cm}$ um discussão argumentativa como scndo: "aquelas que todo mundo admite, ou a maioria das pessoas, ou os filósofos - em outras palavras: todos, ou a maioria, ou os mais notáveis e eminentes". Cabc ressaltar que fundamentar a decisão juridica na accitaçào de premissas pelo senso comum constitui um ponto naturalmente aberto a críticas, pois põc a cerleza preconizada pelo conhecimento positivo em crise.

28. Cf., para uma crítica detalhada da tópica, CANARIS, Claus-Wilhcim, Pensamento Sistemático e Conceito de Sistema na Ciência do Direito, 2a cd., trad. António Menczes Cordciro, Lisboa, Fundaçào Caloustc Gulbenkian, 1996, cap. 7o.

29. Com cfcito, nào faz sentido excluir-sc um ou outro: o pensamento sistemático puro climinaria a instância argumentativa, vedando os respiros de ventilaçào do Dircito; ao passo que a tópica, cxclusivamentc, enquanto cstilo de pensamento, impediria o controle racional da Ciência sobre sua própria praxis jurídica. Em verdade: "Não há, assim, uma alternativa rigida entre o pensamento tópico e o sistemático, mas antes uma complementação mútua" (Canaris, op. cit., p. 277). 
Há que se considerar, ainda, o viés constitucional é intrínseco à metódica estruturante, revelado em nuances de Ciência Política e Teoria Constitucional e consubstanciados essencialmente pela interpretação conforme a constituição e pela constitucionalização dos direitos fundamentais, decorrentes da necessária força normativa da constituição. A força normativa da constituição ("normativ Kraft der" Verfassung") é sua característica essencial, e foi suficientemente identificada por Konrad Hesse, como forma de defender a constituição de ataques pragmáticos em relação ao seu grau de efetividade prática ${ }^{30}$. Esse grau de efetividade prática, por sua vez fora analisado por Ferdinand Lassale, que identificou certos "fatores reais de poder" latentes na sociedade e que a configuravam efetivamente, sendo responsáveis por transformar a constituição numa simples "folha de papel." 31 Lassale trouxe à tona a existência de focos de concentração de poder econômico e político e, principalmente, evidenciou sua intima relação com a constituição de um pais, mostrou a interpenetração entre a realidade e a constituição. A toda constituição, em sentido normativo, subjaz uma constituição real, que sempre se impõe perante aquela, mas que não se apresenta como autêntica, ou em suas próprias palavras, as constituições que se nos apresentam: "no son las Constituciones reales y efectivas, sino las Constituciones escritas; las hojas de papel". ${ }^{32}$ No entanto, a argumentação de Lassale atém-se somente à supremacia da realidade sobre a constituição, admitindo a ligação entre ambas de forma absoluta. Essa relação, no entanto, não se dá de forma absoluta, mas relativa, sendo a força normativa inerente à constituição, o que funde o normativo (sollen) ao fático (sein). ${ }^{33}$ Ora, a constituição traz em si uma pretensão de vigência que, ao conformar a realidade estatal (ainda que relativamente), traduz-se em uma força normativa, legitimando-se enquanto "vontade de constituição" ("Wille zur Verfassung") que, ainda que não consensual, em absoluto, surge como legítima e é constantemente legitimada através de uma praxis constitucional. ${ }^{34}$

Com efeito, e em resumo, rompe-se com o formalismo positivista, captando-se o Direito não como compartimento hermeticamente fechado em si mesmo, mas sim como um sistema aberto e dinâmico em sua força normativa constitucional, servindo-se da argumentação indutivo-problemática, mas escapando da aleatoriedade tópica ao proceder metodicamente no cômputo dos argumentos, apreendendo a praxis

30. HESSE, Konrad, "La Fucrza Normativa de la Constitución", in Escritos de Derecho Constitucional, trad. Pedro Cruz Villalon, Madrid, Centro de Estudios Constitucionales, 1992.

31. LASSALE, Ferdinand, ¿ Que es una Constitución?, trad. W. Roces, Bucnos Aires, Siglo Veinte, 1946.

32. LASSALE, op. cit., p. 71.

33. HESSE, op. cit., pp. 62/63: "La "constitución real" y la "constitución juridica", (...) se hallan en una situación de coordinación correlativa. Se condicionan mutuamente, in ser simplemente dependiente la una de la outra; cabe decir que a la constitución juridica le corresponde tuna significación autónoma, aunque sea sólo relativa"

34. HESSE, op. cit., p. 66. 
juridica em suas dimensões hermenêutica e, fundamentalmente, concreta - trata-se da metódica estruturante do Direito.

A metódica estruturante do Direito funda-se em quatro pilares fundamentais: dogmática, metodologia, teoria da constituição e teoria da norma jurídica ${ }^{35}$. Ora, busca-se, para o momento, fundamentar um eventual controle jurídico de políticas públicas. Mas controle jurídico é visto tradicionalmente como controle de normas juridicas, exclusivamente. Isso traz dificuldades conceituais, quer em relação ao conceito de políticas públicas, quer em relação ao conceito de norma juridica, pois elas, muito embora estejam submetidas ao princípio da legalidade, não se apresentam exclusivamente sob a forma normativa. Daí a importância da teoria da norma desenvolvida por Friedrich Müller no bojo da metódica estruturante, vez que ela alarga o enquadramento jurídiconormativo das normas, permitindo daí o controle das políticas públicas, como se verá.

Para a teoria da norma subjacente à metódica estruturante, a norma não é concebida como "esquema de interpretação da conduta humana"36, mas "Une norme juridique est un modèle d'ordre structuré et concrètement déterminé" 37 em função de um determinado caso a ser resolvido, é um modelo de ordem, um padrão de motivação (Motivationsmuster) das decisões de problemas. A distinção entre a norma e seu texto impede que a este seja legado, por si só, qualquer caráter normativo, sendo-lhe atribuível tão somente a validade (Geltung), distinguindo as normas jurídicas das demais normas sociais, pois impõe aos textos válidos um caráter obrigatório que pode tornar-se violência atual mediante processos e instituições jurídico-políticas. Nesse sentido, a validade não decorre da sua forma enquanto proposição lingüística, mas sim e somente das particularidades contextuais nas quais os textos válidos estão inseridos, remontando-se aqui aos "jogos de linguagem". conforme desenvolvidos por Wittgenstein. Ainda, não se imagine que é o próprio texto válido que será concretizado. Ora, a distinção entre a norma e seu texto impede que seja prefixado à norma um sentido unívoco - algum sentido só vem com o processo de concretização a partir do caso submetido a exame, sendo precisamente essa concretização a responsável pela construção (estruturada) da normatividade. ${ }^{38} \mathrm{E}$ a concretização, por sua vez, significa a densificação dos preceitos jurídicos mediante a fusão de norma e realidade na solução de um caso concreto.

O processo de concretização estruturada da norma tem início a partir dos textos válidos; que são tanto os limites mínimos quanto os limites máximos deste processo - não podem ser desconsiderados no seu início, assim como ao seu fim não se

35. MÜLLER, Fricdrich, Direito, Linguagem, Violencia. Elementos de uma Teoria Constitucional, v. 1, trad. Peter Ncumann, Porto Alegre, Scrgio Antonio Fabris, 1995.

36. KELSEN, op. cil., pp. $18 \mathrm{c} \mathrm{s.}$.

37. MÜLLER, Méthode Juridique, op. cit., p. 201.

38. MÜLLER, Méthode Juridique, op. cit., p. 187; c CANOTILHO, Josć Joaquim Gomcs, Direito Constitucional e Teria da Constituição, 2a cd., Coimbra, Livraria Almedina, 1998, especialmente p. 1076: "A normatividade não é uma "qualidade" da norma; é o efeito do procedimento metódico de concretização" 
pode produzir algo absolutamente contrário a eles. O jurista (Rechtsarbeiter), ao se deparar com um caso prático, toma um ou vários textos válidos e elabora hipóteses textuais (Normtexthypotesen) como ponto de partida para o processo de concretização. Partindo dessas hipóteses textuais, o jurista passa a recolher os elementos fáticos, os dados da realidade que constituem o âmbito fático (Sachbereiche) que, por razões de economia de trabalho, é reduzido e particularizado no âmbito (fático) do caso (Fallbereiche) e, finalmente, no âmbito (também fático) da norma (Normbereiche). Paralelamente, o jurista elabora o programa da norma (Normprogram) a partir da interpretação dos elementos lingüísticos pertinentes ao caso, compondo o que tradicionalmente se chamou de comando da norma, ${ }^{39}$ que não é absolutamente vago nem absolutamente unívoco, indicando espaços de ação metodicamente domináveis nos quais o trabalho jurídico se desenvolve, podendo ser então controlado e legitimado ou criticado. O programa é uma espécie de filtro para a multiplicidade e a variedade de dados empíricos.

Para trabalhar o programa normativo, é necessário que o jurista recorra a recursos interpretativos que remontam, mas não se identificam, àqueles desenvolvidos por Savigny, quais sejam os critérios de interpretação gramatical-literal, sistemático, teleológico, histórico e genético, sendo os três primeiros diretamente referentes aos textos válidos, ao passo que os dois últimos são apenas indiretamente tangentes aos textos válidos. Naturalmente, pode-se pensar numa hipótese de conflito entre estes critérios, o que não é bem o caso, vez que todos têm de ser utilizados em sincronia metódica como caso concreto. No entanto, conforme Friedrich Müller, pode-se pensar numa hierarquia meramente relativa entre eles, em regra prevalecendo os que diretamente se referem aos textos válidos, na medida dessa referência. O critério gramatical-literal é o que busca definir o sentido do comando, é o mais estritamente relacionado aos textos válidos, sendo, portanto, o maior responsável por filtrar os aspectos fáticos relevantes para a composição da norma. Ainda, este critério interpretativo permite definir os limites iniciais e finais do processo de concretização, pois fixa os limites dos textos apresentados. De outro lado, o critério de interpretação sistemática enquadra o programa na totalidade do ordenamento jurídico, impondo uma concepção conjunta, globalizante e unitária do ordenamento jurídico. Por sua vez, o critério teleológico visa à identificação do telos pretendido pela prescrição - este critério sofre importantes restrições, vez que pode deturpar o sentido literal do comando ao buscar-lhe uma finalidade ulterior. Em complemento, o critério histórico de interpretação faz o contraponto entre os textos válidos na atualidade e os textos que uma vez o precederam, identificando as mutações e suas razões históricas, não se referindo direta nem exclusivamente ao textos válidos hipoteticamente selecionados. Finalmente, o critério genético trabalha apenas com textos não válidos, tais como a doutrina, as exposições de motivos, discursos políticos e projetos legislativos. Mas os elementos

39. Sinteticamente, MÜLLER, Méthode Juridique, op. cit., p. 195: "Ensuite, le juriste élabore le programme normatif (...) tiré de l'interpretation de l'ensemble des données linguistiques. A l'aide de ce programme, il choisit enfin le champ normatif (...). la composante objective de la prescription juridique, au sein du champ d'espèce". 
tradicionais de interpretação não esgotam as necessidades argumentativas e interpretativas da metódica estruturante do Direito. Trata-se fundamentalmente, da interpretação conforme a constituição e do princípio da prevalência e defesa dos direitos fundamentais. ${ }^{40}$ Estes dois critérios adicionais exigem uma interpretação material dos textos válidos, introduzindo um viés político-constitucional no processo de concretização normativa.

De fato, a concretização depende da conjunção entre programa e âmbito normativos, produzindo-se uma norma jurídica: "Le programme normatif et le champ normatif composent ensemble la "norme juridique" qui doit être formulée de maniére abstreite et générale" " 4 Vê-se, então, que programa e âmbito da norma formam, em conjunto, a norma jurídica enquanto modelo de motivação de decisões, ainda não se atingindo toda a concretude necessária para a decisão do problema, vez que a norma jurídica, embora já normativa, remanesce relativamente abstrata e geral por não se remeter, por enquanto, ao caso concreto. A partir deste ponto intermediário representado pela norma jurídica, o jurista reporta-se diretamente ao caso concreto, fundindo-os absolutamente em uma específica norma-de-decisão (Entscheidungsnorm) para a solução do caso, desta feita absolutamente concreta e normativa. Logo, a normatividade enquanto capacidade de transformar a norma jurídica em uma norma-de-decisão e, outrossim, remetê-la e imputá-la à primeira, ${ }^{42}$ revela-se dialética e faticamente determinável. Um tal processo de concretização demanda um enquadramento hermenêutico-filosófico adequado, pois rompe com as dicotomias jurídicas clássicas (ser/dever-ser, fato/norma e aplicação/interpretação jurídicas). Todo o processo de construção da norma põe Direito e trabalhador jurídico em contato, esse último necessariamente imerso em uma tradição que se revela em pré-conceitos lingüísticos e substanciais que orienta todo o processo de conhecimento que, por sua vez, desenvolvese em forma de "círculo hermenêtico" ou "espiral hermenêtitica" (Heidegger/ Gadamer), constituindo uma estrutura fático-normativa de sentido em termos de presença ontológica. ${ }^{43}$ Nesse sentido, a concretização hermenêutico-circular do Direito

40. Há que se considerar, que, no que tange especificamente aos critérios constitucionais de interpretação, ć necessário sempre remeter-sc às Constituiçõcs concretas, pois cada uma delas traz princípios c caracteristicas peculiares que $\mathrm{dcvem}$ ser levados $\mathrm{cm}$ conta. Não obstante a particularidade das constituições concretas, ć possível tratar alguns destes critćrios de interpretaçào como genćricos, tais como a interpretaçào conforme a constituição c a defesa dos dircitos fundamentais.

41. Müller, Méthodle Juridique, op. cit., p. 45.

42. Müller, Méthode Juridique, op. cit., p. 189: "La normativité est donc cette capacité prêtée aux normes juridiques de pouvoir être transformées en normes-décisions et de pouvoir alors justifier ces normes-décisions pour autant que ces dernières peuvent, du point de vue de la méthode et du principe de l'Etat de droit, leur être imputée".

43. O termo "pre-scnça" cm nenhuma medida ć sinônimo de "cxistência" ou de "prescnça", mas tcm um significado próximo do original "Dasein", que significa "ser ai", traduzindo a noçào do processo de constituição ontológica do homem $\mathrm{c}$ da humanidade, na medida $\mathrm{cm}$ que ć na pre-sença que o homem constrói scu mundo circundante, relacionando-sc intimamente com o "ser-no-mundo" ("imweltsein") de Heidegger (Heidegger, op. cit., pp. 77 c s.). 
não é simplesmente a redução de uma norma geral a uma norma particular, mas verdadeira construção e produção de uma norma juridica no quadro de solução de um problema dado.

\section{Fundamentação Metodológica de um Controle Jurídico de Políticas Públicas}

Chegou-se, enfim, ao ponto fulcral do estudo. Intenta-se, sobre os pressupostos até aqui assentados, demonstrar porque o controle jurídico de políticas públicas somente é possível, em termos metodológicos, a partir da metódica estruturante do Direito. A metódica é definida como um método de trabalho jurídico, em que: " $A$ função do trabalho juridico é uma função de decisão e dominação, de diferenciação e orientação da sociedade, de distribuição e compensação, de estabilização e legitimação." 44 Sua função, enquanto método de trabalho jurídico, pode ser explanada didaticamente em dois planos - e somente didaticamente existem tais dois planos, vez que na prática são eles absolutamente indivisíveis - quais sejam: (1) no plano jurídico a metódica é uma técnica de imputação, vez que permite formular um mecanismo de condução metódico-racional da decisão jurídica a uma norma; e (2) no plano político a metódica assume a função de deslocar a responsabilidade pela decisão, pela orientação, pela distribuição, pela compensação e pela dominação subjetiva para instâncias normatizantes de uma maneira regularmente aceita como plausivel. Naturalmente, esses dois planos somente podem ser diferenciados para fins de investigação, pois o Direito concreto não os diferencia: a decisão de uma questão é apresentada como imputável ao ordenamento ao passo que, simultaneamente, as conseqüências relativas ao súdito são alocadas na estrutura do Poder Judiciário ou na função mesma do Poder Legislativo.

Nesse sentido, a metódica estruturante do Direito permite confirmar o primeiro pré-conceito desta reflexão, qual seja a existência de um interstício jurídicopolítico passível de ser metódica e racionalmente trabalhado e controlado; a metódica, aliás, confirma a necessidade de tal conexão. A Jurisprudência assume uma função não-só jurídica mas também, e quase que preponderantemente, uma função política. $E$ a Jurisprudência somente o pode fazer no contexto metodológico da metódica estruturante enquanto método de trabalho jurídico além do positivismo - de fato, o positivismo enquanto metodologia científica, i. e., a despeito de suas variantes e respectivas peculiaridades, não viabiliza qualquer discussão política, aliás, mais ainda: não reconhece - e portanto, não pode controlar - as inegáveis influências empíricas da Política sobre o Direito.

Quanto ao segundo pré-conceito, qual seja, o Welfare State enquanto ponto de partida seguro, é inegável assumir a crise desse paradigma estatal e, por óbvio, a relatividade desse pré-conceito teórico. No entanto, e aqui reside um segundo ponto que permite fortalecer e confirmar a metódica como única via metodológica para o controle político de políticas públicas, tal crise é metodologicamente assumida

44. MÜLLER, Fricdrich, Direito, Linguagem e Violência, op. cit., pp. 27/28. 
e o Estado Social de Direito é defendido contra reduções e distorções em suas linhas essenciais: "Elle [a metódica estruturante] n'entend pas être seulement techniquement effetive mais en même temps contribuer à la legitimité de l'Etat constitutionnel. En ce sens ainsi precisé, la rationalité n'est pas seulement une condition de l'Etat de droit, mais aussi de la démocracie et de l'Etat social."45 Vê-se que a metódica traz para o debate científico e metodológico a racionalidade material do Estado Social, o que a faz intimamente relacionada aos direito sociais. Ainda, no que diz respeito à concretização da norma jurídica, o foco central da metódica é sempre os direitos fundamentais, sendo eles fortemente marcados, na prática, por elementos fáticos, ${ }^{46}$ introduzindo-se então, até mesmo no sempre ortodoxo campo da teoria da norma, elementos que permitem traduzir o paradigma estatal social.

Em função disso, o viés tópico e político-constitucional da metódica torna-a apta a lidar com os elementos normativos típicos do Welfare State e que, a despeito de todas as resistências doutrinárias e jurisprudenciais apegadas ao purismo normativo, não são estritamente jurídicos, mas possuem uma carga político-econômica necessariamente aberta à concretização, e. g., os princípios e as normas chamadas "programáticas." 47 Portanto, o segundo pré-conceito, embora relativizado em face das atuais tendências teóricas e políticas, pode ser (e, de fato, assim o é) defendido pela metódica que, contra todas essas recentes tendências, efetivamente o assume como ponto de partida essencialmente inseguro, dispondo-se portanto a aplicá-lo, mas também a questioná-lo e controlá-lo, como critério de racionalidade jurídica. Essas são, a bem da verdade, as razões essenciais que permitem legar exclusivamente à metódica estruturante do Direito a tarefa de justificar e prover subsídios teóricos e metodológicos para o controle jurídico de políticas públicas que se propõe $e^{48}$ Daí porque somente se justifica o controle jurídico de políticas públicas a partir da metódica estruturante do Direito. Um tal controle depende da incessante discussão acerca das relações entre Política e Direito e da legitimidade democrática do Estado Social de Direito, e só a metódica traz esses aspectos para o discurso científico e metodológico do Direito como

45. MÜLLÉR, Méthode Juridique, op. cit., p. 48.

46. MÜLLER, Méthode Juridique, op. cit., p. 66.

47. Cabc fazcr uma obscrvação: as normas "programáticas", simplesmente c sem qualquer sombra de dúvida, não existem. Toda "norma" juridica ("norma" $\mathrm{cm}$ sentido positivista, i.c., cquiparada a scu texto legal) demanda concretização. As normas chamadas "programáticas" somente constitucm hipótescs textuais mais abcrtas c mais propicias à manifestação tópica do Dircito, mas são normas tão-vinculantes c tão-imperativas como todas as demais regras de qualquer ordenamento juridico.

48. MÜLLER, Fricdrich, Direito, Linguagem e Violência, op. cit., p. 32: "Nessa configuração, o Estado de Direito possui funções, que não foram superadas historicannente (...) Ele deve ser defendido, not last, contra as tendências regressivas, (...) motivadas pela atualidade politica. Essa é (...) a precompreensão aqui proposta: não uma tendência de não "questionar" o Estado de Direito: Muito ao contrário: o Estado de Direto seria considerado de forma puramente técnica, se só os modos do traballho juridico devessem ser descritos empiricamente (...) Ele é "questionado " pela proposta de tratar a metódica juridica como totalidade de todlas as indagaçöes segundo: finçẽes - estruturas - modos de trabalho, i.e., pela proposta de simultaneamente questionar como também praticar o Estado de Direito". 
fator de racionalidade e controle das decisões jurídicas. Essa é a essência mesma do controle jurídico de políticas públicas e da reforma proposta: inserir o Poder Judiciário na concretização da vontade social-democrata presente na Constituição brăsileira, o que, à luz de tudo quanto até agora exposto, somente pode ser feito por meio da metódica estruturante do Direito, enquanto postura metodológico-científica madura.

\section{Proposta de Reforma do Poder Judiciário Brasileiro}

Finalmente, tendo em vista todas as considerações até aqui aduzidas e sedimentadas, resta observar com atenção a realidade judiciária brasileira no que diz respeito aos direitos sociais e d̀s políticas públicas para atestar-se a efetiva necessidade de uma qualquer reforma que se pretenda, de forma a identificar as razões que nos levaram a formular a hipótese de reforma ora proposta. $\mathrm{O}$ arcabouço jurídico e institucional brasileiro tem de ser realmente insuficiente para justificar a reforma proposta. São essencialmente dois os mecanismos de defesa dos direitos sociais, a saber, o mandado de injunção e a ação declaratória de inconstitucionalidade por omissão, previstos constitucionalmente pelos art. $5^{\circ}$, inciso LXXI e art. 103, parágrafo $2^{\circ} \mathrm{da}$ Constituição Federal. Não se trata de desenvolver profunda análise de tais mecanismos de proteção constitucional, tarefa já muito bem desempenhada pela doutrina nacional, bastando uma análise estrutural de tais mecanismos para compreender a necessidade do controle jurídico de políticas públicas na forma proposta, adiante delineada.

O termo "controle" tem um significado reflexivo, pois pode desdobrarse tanto para o futuro quanto para o passado, i. e., pode assumir tanto um caráter repressivo ao recair sobre fatos pretéritos (que podem ser atos ou omissões), quanto um caráter preventivo e promocional ao projetar-se para uma atividade futura. Por outro lado, quanto às instâncias procedimentais e à luz do arcabouço jurídico brasileiro, pode o controle representar uma ação individual ou coletiva.

À luz dessas singelas considerações, pode-se perceber claramente que o arsenal constitucional existente no Brasil só é capaz de prover a proteção repressiva de direitos sociais, recaindo o controle individualmente ou coletivamente sobre omissões, cabendo mandado de injunção ou ação declaratória de inconstitucionalidade por omissão, conforme o caso. Esses mecanismos somente viabilizam o exercício do controle após configurado o dano ao súdito, a função de tais institutos é essencialmente reparatória e de pouca eficácia no que diz respeito à implementação e efetivação de direito sociais.

Quanto à ação declaratória de constitucionaliḍade por omissão, não há muito a ser considerado, vez que a própria essência da ação é meramente declaratória, significando muito pouco no que diz respeito à implementação de políticas públicas para efetivar direitos sociais: o Poder Judiciário se restringe a, timidamente, comunicar a falência dos direitos sociais aos órgãos competentes, não havendo nada além disso a ser feito.

O grande ponto de discussão gravita em torno do mandado de injunção. Inspirado pelos writs of injunction do Common Law, notadamente pela affirmative 
action e pela structural injunction, o mandado de injunção teve originalmente um caráter mandamental de implementação do direito pleiteado. Ora, de fato, tal remédio configuraria grande passo constitucional no sentido de promover e defender direitos sociais, vez que ensejaria a participação determinante do Judiciário na efetivação do direito desguarnecido. No entanto, a jurisprudência constitucional brasileira se encarregou de minar peremptoriamente a eficácia do dispositivo, entendendo tratar-se de norma não auto-aplicável e, como tal, incapaz de solucionar o caso concreto. ${ }^{49} \mathrm{Em}$ adição, ainda que o entendimento jurisprudencial houvesse mantido o sentido original do mandado de injunção, ele não seria plenamente satisfatório para implementar direitos sociais, pois os restringiria à defesa individualizada dos direitos sociais, fazendo com que se perdesse a noção da necessária efetivação desses direitos mediante a implementação de políticas públicas.

Cabe agora, rapidamente, dizer uma palavra sobre a ação civil pública. Embora ela seja, na prática, usada para a defesa de direitos "coletivos" ela não representa, estritamente, um instituto de defesa dos direitos sociais, pois destina-se a proteger o consumidor, o meio ambiente e demais interesses difusos e coletivos que, em verdade, não se identificam conceitualmente aos direitos sociais, econômicos e culturais. Aliás, a recente medida provisória n. 2102-26 de 2000 incluiu parágrafo único ao artigo primeiro da lei da ação civil pública (Lei n. 7.347, de 24 de julho de 1985), excluindo expressamente a possibilidade de que se sirva do instituto para a defesa de direitos de natureza previdenciária e trabalhista - em outras palavras, consumou a inutilidade da ação civil pública na defesa de direitos sociais por excelência.

Não-obstante tais considerações, pouco desenvolvidas e tampouco sistematizadas, já que meramente estruturais, relativas aos referidos remédios constitucionais, não se há de negar que recentes avanços têm sido apresentados pelo Poder Judiciário brasileiro na defesa da coletividade. Mais ainda assim, até mesmo tais avanços devem ser avaliados e criticados. Isso porque nesses parcos avanços, a jurisprudência se move sem uma orientação vetorial definida e consciente, isto é, atua meio que às cegas, reagindo por vezes a pressões políticas, por vezes a pressões da opinião pública. É fato que em tais circunstâncias, muitas vezes os direitos sociais são efetivamente implementados de maneira satisfatória, mas isso não permite concluir pela existência de uma orientação metodológica e científica da Jurisprudência brasileira, aproximando-se tais avanços de um "pragmatismo sem direção"s0 que configura

49. Cf., paradigmaticamente, o mandado de injunção 107-3-DF, Rel. Min. Morcira Alves, 23/11/89. Contrastante ć a cxperiência jurispradencial nortc-americana, podendo-sc apontar alguns casos excmplares: Brown v. Board of Eclucation of Topeka, de 1954, cm que o Chief Justice Warren decidiu pela implementação de politica cducacional para acabar com a segregação racial nas cscolas, inclusive homogencizando as grades curriculares; os casos Norman v. Baltimore \& OhioRuilroad, United States et. al. v. Bankers Trust Co. et al., Nortz v. United States c Perry v. United States, todos decididos uniformemente para consolidar politica pública financeira de estabilizaçào monctária no governo de Rooscvelı; c os Wyall cases, cm que o Poder Judiciário do Alabama praticamente assumiu a administração da rede hospitalar.

50. MÜLLER, Métodos de Trabalho do Direito Constitucional, 2a cd., trad. Peter Naumann, São Paulo, Malhciros, 2000, pp. 37/38. 
verdadeira serindipidade jurisprudencial e, portanto, muitas vezes sujeitos a confirmações e desconfirmações, fluxos e refluxos e guinadas tortuosas, justamente em função da ausência de uma sólida orientação metodológica consciente de si mesma.

Aqui se situa a principal e derradeira justificativa para o controle jurídico de políticas públicas conforme proposto: acabar com a serindipidade jurisprudencial ao fazer com que o Poder Judiciário tome conhecimento e consciência das próprias funções que assumiu com a Constituição, de 1988, perante o Estado Social nacional no sentido de implementar os direitos sociais, econômicos e culturais mediante ativa participação na implementação de políticas públicas. Somente coordenando o procedimento com a metodologia e a ideologia subjacentes é possível haver uma autêntica praxis constitucional. Isso o que se preténdeu com a presente proposta de reforma do Poder Judiciário brasileiro: aproximá-lo da implementação de políticas públicas fazendo convergir, em última instância, prática e ideologia constitucionais.

E a aproximação que se pretende, se operada novamente de forma repressiva, de nada inovaria o ordenamento jurídico brasileiro, pelo menos não de forma plenamente satisfatória. O controle jurídico de políticas públicas é tipicamente preventivo, ou melhor, tal controle não se exerce em um singular determinado momento, mas constitui atividade constante de vigília da atividade governamental. Dessa forma, insere-se tal controle no bojo do planejamento da atividade governamental, pois consiste precisamente na verificação e controle do cumprimento e da execução dos programas de governo..$^{51}$ Não se trata de controlar apenas a higidez orçamentária, o que pode ser feito através do procedimento legislativo ordinário. Trata-se de verdadeiro e constante monitoramento da atividade governamental pelo Poder Judiciário. E tal monitoramento depende de uma Justiça constitucional atuante.

Nesse ponto reside mais uma crítica que pode ser feita ao Sistema Judicial brasileiro: a ausência de um tribunal constitucional responsável exclusivamente pela concretização da Constituição. Cabe ressaltar que a polêmica em torno desse ponto específico é bastante acirrada, havendo quem defenda o Supremo Tribunal Federal como autêntica Corte Constitucional brasileira e havendo também aqueles que não o reconhecem como tal. ${ }^{52}$ Sem adentrar nas minúcias de tal polêmica, o Supremo Tribunal Federal, apenas por deter competência constitucional originária em certas matérias, não se transforma em típico tribunal constitucional. Além disso, acumula funções e competências excessivas e não constitucionais, ao mesmo tempo em que, ao ser composto por nomeação do poder executivo, tem sua independência política

51. Cf. COMPARATO, "Ensaio sobre o Juizo de Constitucionalidade de Políticas Públicas", op. cit.; bem como "A Organização Constitucional da Função Plancjadora", in Revista Trimestral de Direito Público, n." 8, São Paulo, 1994.

52. SANCHES, Sidney, "O Supremo Tribunal Federal do Brasil na Constituição de 1988”, in VVAA, Legitimidade e Legitimação da Justiça Constitucional, Lisboa, Coimbra Editora, 1995: "Não há no Brasil uma Corte Constitucional propriamente dita (...)". Em oposição, VELLOSO, Carlos, "O Supremo Tribunal Federal: Cortc Constitucional" c "Do Poder Judiciário: organização c competência", in Revista de Direito Administrativo, Rio de Janciro, ns. 192 (1993) c 200 (1995), respectivamentc. 
naturalmente posta em questão, quando seu compromisso deveria ser exclusivamente a concretização constitucional.

Com efeito, a inserção do Poder Judiciário no processo de concretização dos direitos sociais, econômicos e culturais, em função de seu inexorável caráter constitucional, tem que se dar mediante a praxis constitucional, em outras palavras, por meio do desenvolvimento e atuação da Justiça constitucional. E por mais distante de nossa realidade que uma tal proposta possa parecer, é forçoso reconhecer o papel central desempenhado pelos tribunais de Justiça constitucional no moderno Constitucionalismo. ${ }^{53} \mathrm{E}$ a atuação da Justiça constitucional possui, sempre, e de acordo com seu substrato metódico-estruturante, três dimensões essenciais: uma dimensão institucional-normatizante, representada pelo processo desenvolvido conforme determinado trâmite procedimental responsável pelas decisões; uma dimensão tópicoargumentativa, na medida em que consubstancia uma atividade interpretativa e criativa do tribunal subjacente a cada decisão; e uma dimensão político-constitucional, pois sua atuação é inexoravelmente jurídica e também política e, como tal, em estrita consonância com o governo e a atividade dos demais poderes do Estado. ${ }^{54}$

Imediatamente surge a questão "Qui custodiet custodes?" quer dizer, saber a quem confiar o controle daqueles que controlarão as políticas públicas, pois esse controle também não será ilimitado. Sob pena de recair-se em uma regressão ao infinito, a melhor solução é ainda a apontada pela justiça constitucional dos EUA, consistente na political question doctrine e no judicial self-restraint que lhe é inerente. Observe-se, entretanto, que "a doutrina das questões políticas não pode significar a existência de questões constitucionais isentas de controlo" s5 apenas serve a balizar o controle evitando-o apenas nas situações em que ele caracterizar-se-ia uma efetiva ingerência funcional, prejudicando a vida do Estado. De fato, é possível identificar uma political question sempre que, disjuntivamente, não houver absolutamente, nenhuma norma constitucional aplicável ao caso; ou dizer respeito a decisão do caso apenas e tão-somente ao regime de competências da divisão de poderes; ou ainda tratarse de questão que, em última análise, deve ser decidida pelo eleitorado, diretamente. ${ }^{56}$ Claramente, não havendo instância superior de controle, cabe aos membros do tribunal constitucional o judicial self-restraint, a consciência de uma auto-contenção que situe o juiz em um meio termo entre o ativismo e o contencionismo judiciais. ${ }^{57}$ Isso resume

53. QUEIROZ, op. cit., p. 126.

54. CANOTILHO, Direito Constitucional, op. cit., p. 1167.

55. CANOTILHO, Direito Constitucional, op. cit., p. 1170.

56. Cf. QUEIROZ, op. cit., p. 131.

57. O ativismo judicial exacerbado ć cfetivamente perigoso. Mas não ć uma caracteristica exclusiva do controle juridico de políticas públicas $\mathrm{e}$ da proposta aqui claborada: um importante excmplo de ativismo judicial pode ser encontrado na jurisprudência da Suprema Corte norte-americana no momento imediato à implantação do New Deal de Roosevelt, dessa feita $\mathrm{cm}$ sentido contrário às inovações trabalhistas $\mathrm{c}$ sociais implementadas pelo governo. 
e demonstra como a praxis constitucional é um constante processo de legitimação, tanto da Justiça constitucional e da própria constituição como de cada uma de suas decisões, o que, novamente, só faz sentir mais contundente a necessidade de pressupostos metódico-estruturantes para tanto.

Mas poder-se-ia indagar pela natureza das políticas públicas, quer dizer, procurar defini-las como atos administrativos ou leis, para então mensurar o controle e, dessa sorte, limitá-lo. Ora, para viabilizar o controle de políticas públicas não é necessário, aliás, é absolutamente inútil, buscar uma estandartização dogmática das políticas públicas. De fato: "o acto ou é constitucional ou-não o é. (...) o acto encontra-se sujeito a um controle de constitucionalidade desde que para tanto se apresente como susceptivel de conformação normativa, ou seja, desde que se apresente como uma questão juridica, como tal justiciável." 58 Despiciendo classificar rigidamente as políticas públicas como "atos administrativos" ou "normas": são atividades governamentais constitucionalmente vinculadas que devem ser captadas como o vetor estatal precípuo de realização de Justiça social, para então formular-se um problema juridico-constitucional que carece ser decidido. E para determinar um problema jurídico-constitucional é absolutamente suficiente a political question doctrine, ou seja, não pode a política pública sujeita a controle constituir-se uma questão exclusivamente não-jurídica, por exemplo, não se pode tratar de uma situação não-respaldada constitucionalmente, bem como da competência para tomar a iniciativa na implementação da referida política pública, ou ainda questionar matérias essencialmente sujeitas ao voto popular.

Finalmente e após todas as conclusões parciais apontadas, chega-se ao ponto final da especulação, talvez o mais ambicioso (e com certeza o menos otimista) deste estudo. Ressalte-se que não se trata de remodelar todo o Poder Judiciário brasileiro, mas tão somente oferecer uma forma de aproximação entre esse poder e as questões sociais. Não se trata, outrossim, de imputar ao Poder Judiciário toda a responsabilidade pela efetivação dos direitos sociais, busca-se apenas romper com seu isolamento exacerbado e socialmente alienado, viabilizando o controle jurídico de políticas públicas e a defesa individual contra omissões na efetivação de tais direitos. Eis então, a seguir, as linhas mais gerais de proposta de hipotética emenda constitucional, de lege ferenda, capaz de tornar o Poder Judiciário atuante na implementação de políticas públicas para a efetivação de direitos sociais, consoante os preceitos científico-metodológicos da metódica estruturante do Direito.

Proposta de Emenda Constitucional (de lege ferenda)

Cria o Tribunal Constitucional do Brasil. Dá nova redação a dispositivos constitucionais. Revoga dispositivos constitucionais.

Art. $1^{\circ}$. O inciso LXXI do art. $5^{\circ}$ da Constituição Federal passa a vigorar com a seguinte redação:

"LXXI - conceder-se-á mandado de injunção sempre que omissão normativa ou administrativa de qualquer órgão do Poder Público 
tornar inviável o exercício dos direitos e liberdades constitucionais e das prerrogativas inerentes à nacionalidade e à cidadania, devendo ser o pedido plenamente provido pela via judicial no caso em espécie;

a) o mandado de injunção processa-se exclusivamente perante o Tribunal Constitucional do Brasil;

b) o rito do mandado de injunção segue o rito do mandado de segurança."

Art. $2^{\circ} . \mathrm{O}$ art. 92 da Constituição Federal passa a vigorar com a seguinte redação:

"Art. 92. São órgãos do Poder Judiciário:

I) o Tribunal Constitucional;

II) o Supremo Tribunal Federal;

III o Superior Tribunal de Justiça;

IV) os Tribunais Regionais Federais e os Juizes Federais;

V) os Tribunais e Juízes do Trabalho;

VI) os Tribunais e Juizes Eleitorais;

VII) os Tribunais e Juizes Militares; e

VII) os Tribunais e Juizes dos Estados e do Distrito Federal."

Art. $3^{\circ}$. O art. 51 da Constituição Federal é acrescido de um inciso, com a seguinte redação:

"Art. 51. Compete privativamente à Câmara dos Deputados: (...);

VI) eleger os juizes do Tribunal Constitucional, nos termos do art. 101."

Art: $4^{\circ}$. É criado o Tribunal Constitucional do Brasil, órgão integrante do Poder Judiciário. O Tribunal Constitucional será composto e terá suas competências estabelecidas nos termos dos artigos 100-A e 100-B da Constituição Federal, incluídos por esta Emenda e com a seguinte redação:

"Art. 100-A. O Tribunal Constitucional do Brasil é composto por nove juízes, eleitos pela Câmara dos Deputados pela maioria absoluta de seus membros, dentre bacharéis em direito, pelo prazo de nove anos, sendo vedada a reeleição.

$\S 1^{\circ}$. Cada um terço dos juízes será eleito mediante a escolla em lista tríplice, apresentada, respectivamente, pelo Supremo Tribunal Federal, pelo Ministério Público da União e pela Ordem dos Advogados do Brasil; $\S 2^{\circ}$. Cada um terço dos juízes será renovado a cada período de três anos.

Art. 100-B. Compete ao Tribunal Constitucional, privativa e exclusivamente, defender e concretizar a Constituição Federal, cabendolhe, em decisão definitiva e inapelável:

I) processar e julgar originariamente:

a) o mandado de injunção, nos termos do art. $5^{\circ}$, inciso LXXI;

b) a ação direta de inconstitucionalidade de política pública, em função de qualquer atividade ou omissão de qualquer órgão do Poder Público, 
de caráter normativo ou administrativo, que esteja em dissonância com planejamento previamente estabelecido pelo órgão competente; 1) a sentença que julgar proc'edente a ação direta de inconstitucionalidade de políticas públicas torna nula a atividade praticada em dissonância com o planejamento e vincula o órgão competente ao suprimento, em noventa dias, da omissão inconstitucional;

2) são competentes para propor essa ação:

I) a Mesa da Câmara dos Deputados;

II) a Mesa do Senado Federal;

III) a Mesa da Assembléia Legislativa;

IV) o Procurador-Geral da República;

V) o Conselho Federal da Ordem dos Advogados do Brasil;

VI) Partido Político com representação no Congresso Nacional; e

VII) Entidade de classe de âmbito nacional, confederação sindical ou entidades para-estatais de âmbito nacional.

a) a ação direta de inconstitucionalidade de lei ou ato normativo federal ou estadual e ação declaratória de constitucionalidade de lei ou ato normativo federal;

b) o mandado de injunção, quando a elaboração da norma regulamentadora for atribuição do Presidente da República, do Congresso Nacional, da Câmara dos Deputados, do Senado Federal, das Mesas de uma dessas Casas Legislativas, do Tribunal de Contas da União, de um dos Tribunais Superiores, ou do próprio Supremo Tribunal Federal;

II) julgar, mediante recurso extraordinário, as causas decididas em única ou última instância, quando a decisão recorrida:

a) contrariar dispositivo desta Constituição;

b) declarar a inconstitucionalidade de tratado ou lei federal;

c) julgar válida lei ou ato de governo local contestado em face desta Constituição.

$\S 1^{\circ}$. A argüição de descumprimento de preceito fundamental, decorrente desta Constituição, será apreciada pelo Tribunal Constitucional, na forma da lei;

$\S 2^{\circ}$. As decisões definitivas demérito, proferidas pelo Tribunal Constitucional, nas ações de inconstitucionalidade de políticas públicas, declaratórias de constitucionalidade de lei ou ato normativo federal, produzirão eficácia contra todos e efeito vinculante, relativamente aos demais órgãos do Poder Público."

Art. 5". Revogam-se as alíneas "a" e "q". do inciso I e os parágrafos primeiro e segundo do inciso III do art. 102, e a alínea " $h$ " do inciso I do art. 105.

Art. $6^{\circ}$. Esta Emenda Constitucional entra em vigor na data de sua publicação. 


\section{Três Objeções Imediatas}

A primeira crítica a ser enfrentada está preponderantemente assentada no campo da Ciência Política. Formular-se-ia a crítica questionando-se a legitimidade democrática dos juízes para o julgamento de políticas públicas levadas a cabo pelo governo. Ora, argumentariam os contendores, um tal controle juridico conforme proposto constitui verdadeira afronta à democracia, justamente por ser exclusivídade de uma instituição não democraticamente eleita - o tribunal.

Para restringir-se a democracia por qualquer maneira, é antes necessário compreendê-la. O termo "democracia" é alardeado aos quatro ventos, sendo utilizado de forma tão abrangente e em situações tão diversas entre si que acaba por esvaziarse de sentido. ${ }^{59}$ A noção de democracia, em função desse uso despudorado, traz em si uma associação imediata que, se indubitavelmente importante, não pode ser assumida sem qualquer questionamento. Com efeito, "democracia" traz a tiracolo a noção de representação política, sendo que tal convergência remonta aos estudos utilitaristas de Stuart Mill - ora, nada mais óbvio: se todo poder emana do povo mas, por razões práticas igualmente óbvias, por ele não pode ser diretamente exercido em uma sociedade industrial, há que se socorrer do sistema representativo. A suplantação da monarquia, através das revoluções liberais, trouxe a necessidade prática da adoção do sistema da representação política no mundo ocidental que, consolidado em uma determinada moldura, fundou-se em certos pontos centrais: a vontade dos representantes não é necessariamente coincidente com a vontade dos representados e isso não a torna vinculada a estes, ao contrário, garante a independência da vontade representante perante a representada, sendo tal independência garantida pelo voto e pela irrevogabilidade do mandato representativo. Toda essa estrutura é garantida pela supremacia do Poder Legislativo no quadro da separação de poderes.

Em função da convergência operada tanto pelo pensamento de Mill quanto pela ascensão burguesa, sistema representativo e democracia legitimavam-se reciprocamente, na medida em que um somente era viável pelo outro - impensável democracia sem representação, sendo a recíproca necessariamente verdadeira. Há ainda uma ulterior associação, mais sutil que a primeira e que demanda maior atenção: por terem sido historicamente inaugurados no contexto das revoluções liberais do século XVIII, democracia e sistema representativo não só passaram a implicar-se mutuamente mas, outrossim, foram absolutamente vinculados ao liberalismo, de forma que a democracia inevitavelmente trazia atrelada a si, na maioria das vezes, considerações quanto à representatividade e liberdade, fundamentalmente a liberdade em seu sentido

59. Cf., a respeito do esvaziamento conccitual da democracia, SARTORI, Giovanni, Teoria Democrática, trad. Francisco M. da Rocha Filho c Oswaldo Blois, Rio de Janciro, Fundo de Cultura, 1965, pp. 22/23. Com cfeito, praticamente nenhum governo sc auto-intitula "anti-democrático" explicitamente, muito embora uma efetiva democracia seja realmente dificil de ser encontrada na prática. 
negativo (liberdade dos modernos).$^{60}$ Mas não é prudente já estancarmos neste ponto tais considerações ainda não satisfazem a atual delineação da democracia, sendo necessário ir um pouco mais além. Ora, conceitualmente convergindo representação política e regime democrático no bojo do liberalismo, o resultado é forçosamente uma concepção de democracia essencialmente individualista e (por que não dizê-lo?) utilitarista, pois fundada e concebida de acordo com os preceitos típicos do pensamento de Locke, Bentham e Stuart Mill: uma comunidade sob regime democrático é composta de individuos essencialmente livres e iguais e que exercem o poder político votando em seus representantes também livres e iguais.

No entanto, o controle jurídico de políticas públicas se insere em ụ̣ contexto substancialmente diverso dessa democracia individualista, embora tal visão ainda persista. Trata-se da democracia das sociedades de massa, na qual o indivíduo sucumbe ante os múltiplos grupos de pressão, destacando-se as oligarquias políticas enquanto focos centralizados de poder, pontuais e relativamente autônomos, o que, por sua vez, só faz exacerbar a discrepância entre a vontade representante e a vontade representada. Como já visto, a sociedade industrial trouxe profundas alterações paradigmáticas, ressaltando-se dentre elas a apresentação do Welfare State. O Estado Social abriu os horizontes da participação popular aos campos econômico e cultural, trazendo-os para o âmbito da liberdade do cidadão, agora em sentido positivo (liberdade dos antigos), introduzindo a noção de democracia social no contexto político ocidental. E a democracia social difere em muito da democracia individualista, pois mescla, ou tende a mesclar, institutos de representação política a institutos de participação democrática direta. ${ }^{61}$ De fato, a eleição popular enquanto meio de pôr em prática a representatividade política, não é em si e por si mesma suficiente. A eleição nada mais é que uma técnica de escolha dos representantes, um mero instrumento de arranjo da representação política, e não princípio fundamentante da democracia. Sente-se, com a social-democracia, um grave abalo na tradicional concepção de democracia liberal e individualista fundada na representação política tradicional.

Ora, a objeção apresentada tem de ser respondida nesse ponto crítico da democracia, qual seja, levando-se em consideração o impacto social-democrático após seu desenvolvimento liberal. Nesta esteira, é necessário considerar que as eleições não são suficientes para eximir os governantes de controle sobre o poder político exercido, a não ser em uma linha de argumentação efetivamente muito mal-intencionada. Em

60. Cf. BERLIN, Isaiah, Quatro Ensaios sobre a Liberdade, trad. Wamberto Hudson Ferreira, Brasilia, Universidade de Brasilia, 1981; c CONSTANT, Benjamin, Da Liberdade dos Antigos Comparacla à Liberdade dos Modernos, trad. Loura Silvcira, $\mathrm{sem}$ local, $\mathrm{sem}$ data, pp. 9-25. Quanto à identificação opcrada entre libcralismo c democracia, vcja-sc BOBBIO, Norbcrto, O Futuro da Democracia: uma defes'a das regras do jogo, 6a ed., trad. Marco Aurćlio Nogucira, Rio de Janciro, Paz c Terra, 1997, p. 20: "Disto segue que o estado liberal é o pressuposto não só histórico mas jurídico do estado democrático"

61. Cf. o parágrafo único do artigo lo c os incisos I, II c III do artigo 14 da Constituiçào Federal. A respcito, BENEVIDES, Maria Victoria de Mcsquita, A Cidadania Ativa: referendo, plebiscito e iniciativa popular, 2a cd., São Paulo, Ática, 1996. 
segundo lugar, não se trata o controle pelo Poder Judiciário de uma patologia, mas sim de uma adequação institucional à ideologia do Estado Democrático Constitucional ${ }^{62}$ Mais ainda, tal controle é antes necessário que prejudicial para a manutenção do regime democrático, pois viabiliza a constante fiscalização do adequado cumprimento das promessas eleitorais dos governantes. E, no mais, todas as atividades do poder público, inclusive o próprio controle jurídico de políticas públicas, têm de estar submetidas à constituição. As eleições são apenas e exclusivamente o primeiro momento de um governo democrático, mas não-esgotam de forma alguma a sua essência, nem escapam ao controle de constitucionalidade.

Traduzir a democracia exclusivamente em termos eleitorais configura um conceito vazio e formal de democracia, pois impede a consideração da gênese da vontade popular: "Eleições livres com uma opinião que não seja livre (...) nada significam", ${ }^{63}$ retirando-lhe a carga ético-política de governo e imputando-lhe a mera condição de técnica decisória. Com efeito, conforme a clássica trilogia politica de Aristóteles, as formas de governo se dividem em três, conforme um critério quantitativo e um critério qualitativo: o governo de um só é, em sua forma pura, a monarquia, que pode corromper-se em tirania; o governo de um conjunto de pessoas é, na forma pura, a aristocracia que, por sua vez, pode ser corrompida e transformada em oligarquia; e finalmente, a democracia é a forma pura do governo do maior número de pessoas, mas que pode acabar corrompendo-se em demagogia. Ora, tendo em vista a nova configuração da democracia em uma sociedade de massas, contrapor-se ao controle de políticas públicas proposto constitui-se, de fato, um efetivo atentado à democracia, pois impede que o Poder Judiciário tenha acesso à praxis política da comunidade, veda-lhe o controle dos governantes e consuma sua irresponsabilidade perante $o$ eleitorado, torna a democracia uma técnica operada pelos candidatos, muitas vezes de forma cínica e leviana, impede o resguardo da social-democracia e dos direitos sociais, econômicos e culturais: torna-se mansa e crassa demagogia.

No campo da teoria constitucional, poder-se-ia objetar que o controle jurídico de política públicas proposto configura uma violação expressa do princípio da separação de poderes, o que, no caso brasileiro, seria mais grave, em se tratando de cláusula pétrea constitucional (inciso III do parágrafo $4^{\circ}$ do art. 60).

A separação de poderes é hoje um dogma constitucional. Tanto é assim que se acabou por converter em um elemento conceitual definidor da Constituição. Tal doutrina veio a lume com as reflexões de Montesquieu, buscando uma forma de limitar

62. LOEWENSTEIN, Karl, Teoria de la Constitución, 2a ed., trad. Alfredo Gallego Anabitartc, Barcclona, Ediciones Aricl, 1970, pp. 304/305 c s.. Corroborando o entendimento de que nào há oposiçào, mas complementaridade, entre Justiça constitucional c democracia, cf. VVAA, Legitimidade e Legitimação da Justiça Constitucional, Lisboa, Coimbra Editora, 1995; MÜLLER, Méthode Juridique, op. cit., p. 128 c MÜLLER, Quem É o Povo? A questão fundamental da democracia, 2a cd., trad. Peter Naumann, São Paulo, Max Limonad, 2000.

63. SARTORI, op. cit., p. 89. Ainda, ibidem, de modo mais cćtico: "Nos dias que correm, podemos descobrir uma opinião popular que não representa em nenhum sentido expressivo a opinião do povo". 
o poder do soberano sobre o súdito, preservando sua liberdade - aqui, novamente, em sentido negativo. ${ }^{64}$ A divisão dos "poderes" (funções estatais) tinha a função de proteger o cidadão, em diametral oposição à monarquia, argumentando que "tudo estaria perdido se o mesmo homem, ou o mesmo corpo dos principais, ou dos nobres, ou do povo exercesse os três poderes" ${ }^{65}$ Ora, tal concepção, livrando o indivíduo do poder do monarca e estabelecendo a supremacia legislativa, constituiu a pedra de toque do Constitucionalismo dos séculos XVIII e XIX, apresentando-se-lhe de tal maneira intrínseca que já não era possível pensar-se em constituição sem separação de poderes. Ainda, levando-se em conta um positivismo jurídico todo focado na lei e na subsunção do fato à norma, produção e aplicação do Direito apareciam como momentos distintos e independentes e, com tais, atribuídos a poderes igualmente distintos independentes. A dogmatização do princípio da separação de poderes promovida pelo Constitucionalismo e pelo positivismo legalista e, ademais, atestada pelas constituições liberais, afastou o Poder Judiciário das questões políticas, forçando: a compartimentalização de Direito e Política e, em conseqüência, apresentando qualquer interpenetração entre eles como uma patologia ${ }^{66}$

No entanto, mais uma vez o impacto social-democrata se fez sentir, desta feita em relação ao dogma da separação de poderes. Para bem atestar-se a relativização do princípio, faz-se oportuno recorrer às considerações de Karl Loewenstein a respeito de "sistema politico". ${ }^{67}$ Sistema político designa uma comunidade em que as instituições e a ideologia dominante estão em harmonia, funcionando em conjunto e uma pela outra: uma determinada ideologia (independentemente de qualquer consenso a seu respeito) molda suas instituições fundamentais, as quais só operam adequadamente à luz da ideologia subjacente.

Ora, não se reconhecendo o controle de políticas públicas, conforme proposto, o que se tem a partir do impacto social-democrata sobre o dogma da separação dos poderes é exatamente uma patente desfiguração do sistema político, na medida em que a ideologia politica constitucional fora substituida mas, não-obstante, foram mantidas as instituições e, dentre elas, o próprio Poder Judiciário, obrigando a ideologia socialdemocrata a trabalhar na estrutura institucional herdada do liberalismo. Nesse contexto,

64. MONTESQUIEU, Charles de Sccondat, Baron de, O Espirito das Leis, trad. Cristina Murachco, São Paulo, Martins Fontes, 1996, livro XII, cap. 11I, p. 166: "Deve-se ter em mente o que é a independência e o que é a liberdade. A liberdade é o direito de fazer tudo o que as leis permitem; e se un cidadão pudesse fazer o que elas proibem ele já nào teria liberdade, porque os outros homens também teriam este poder"

65. MONTESQUIEU, op. cit., livro XI, cap. VI, p. 168.

66. Cf. FERRAZ JR., "O Judiciário frente à Divisão dos Poderes: um Principio cm Decadência?", in Revista Trimestral de Direito Público, n. 9, Sào Paulo, 1995, cspccialmcnte p. 41: "A neutralização foi acompanhada de uma desvinculação progressiva que iria sofrer o direito em suas bases sociais. Inicialmente, ela significaria a neutralização política, para depois exigir distanciamento ético". Rcssaltcsc que tal neutralização não sc dá cmpiricamentc, mas apenas institucionalmentc, scndo portanto desconsiderada (mas não climinada) toda c qualquer influência política sobre o Poder Judiciário.

67. LOEWENSTEIN, op. cit., pp. 31 c s.. 
não há como a instituição funcionar adequadamente, uma vez em descompasso com a ideologia constitucional. O próprio princípio da separação de poderes, enraizado na proteção da liberdade negativa, não se deu conta das mudanças operadas pelo Estado Social fundado essencialmente na liberdade positiva, mantendo-se atrelado à sua dogmatização.

Aliás, nunca se observou, nem era esse o propósito de Montesquieu, uma total e absoluta separação entre os poderes. Basta tomar o exemplo constitucional brasileiro: o Poder Executivo não exerce só a função administrativa, mas participa também da função legislativa, com fundamento no art. 59, incisos IV, V e VII, combinado com o art. 84, incisos III, IV, V da Constituição Federal; o poder legislativo exerce a função de julgamento e controle do Poder Executivo, conforme os incisos I e II do art. 52; e o próprio Poder Judiciário, por sua vez, pode prolatar sentenças e decisões de tal forma gerais e abstratas que acabam por assumir, por assim dizer, feição de lei, uma vez que são válidas erga omnes indistintamente, como no caso previsto pelo art. 102, inciso I, alínea "a", parágrafo $2^{\circ}$ da Constituição de 1988.

$\mathrm{O}$ isolamento de cada poder em redomas incomunicáveis trava e compromete o funcionamento institucional do Estado Social - distorce o sistema político: a dogmatização da fórmula original da divisão de poderes acabou por promover o isolamento dos poderes entre si. Exacerbada nesses termos, a separação de poderes produz efeito contrário ao pretendido, pois ao invés de preservar a liberdade, acaba criando três esferas autônomas de poder, cada qual senhora de si em seu isolamento, tão-soberana e inacessivel quanto as demais, submetendo o cidadão não a uma, mas a três instâncias de poder absoluto. De fato, a "nova" liberdade (positiva, dos antigos) a ser protegida exige maiores e mais eficientes controles políticos, "a responsabilidade do juiz alcança agora a.responsabilidade pelo sucesso politico das finalidades impostas aos demais poderes pelas exigências do estado social" ${ }^{88}$ Destarte, resta demonstrado que o controle juridico de políticas públicas só faria aumentar a responsabilidade do governo, incrementando o entrosamento entre os poderes estatais e aperfeiçoando o sistema político nacional.

A derradeira objeção a ser enfrentada, desta feita de caráter técnico-jurídico, diz respeito à discricionariedade administrativa, i. e., a qualidade própria de determinados atos da administração pública que não se sujeitariam a controle. As políticas públicas seriam, então, definidas exatamente como atos administrativos discricionários e, como tais, livres de controle judicial - a proposta de controle implicaria eliminação da discricionariedade administrativa na implementação de políticas públicas, pois permitiria a revisão do mérito da atuação administrativa, contrariando um dos postulados fundamentais do Direito Administrativo tradicional. Tem-se de identificar, pois, os campos em que a atividade administrativa se desenrola de maneira discricionária e verificar se as políticas públicas podem ser assim descritas sendo, portanto, isentas do controle proposto.

A noção de ato administrativo particulariza a administração pública em uma unidade conceitual que, na verdade, é menos efetiva que ideal. Note-se: outra vez,

68. FERRAZ JR., “O Judiciário frente à Divisão dos Poderes: um Principio cm Decadência?”, $o p$. cit., p. 45. 
apego a dogmas sem a devida atençạo às novidades inerentes à mudança paradigmática do Estado no século XX provoca perigosas distorções conceituais. Uma delas é representada pelo conceito de ato administrativo discricionário, geralmente contraposto ao ato administrativo vinculado. Diz-se "vinculado", porque plenamente determinado por lei, formal e substancialmente; e "discricionário", em função de uma certa independência substancial - o mérito do ato não pode ser judicialmente questionado.

Com efeito, trata-se de uma concepção restritiva do Đireito Administrativo que não se deu conta da transição paradigmática do Estado. A administração pública tornou-se mais complexa e mais abrangente, não se restringe ao exercício do Poder de Polícia, mas busca implementar objetivo materiais, notadamente a consecução das finalidades econômicas e sociais previstas pela Constituição - de fato, o Estado "legislativo" fora substituida pelo Estado "administrativo", 69 o Welfare State promoveu o aperfeiçoamento da administração pública, que assumiu em um sentido substancial e teleologicamente orientado para a transformação material da sociedade, diametralmente oposto à tradicional moldura formal e policial típica do Estado Liberal.

Nessa esteira, reduzir a atividade administrativa ao ato administrativo isoladamente considerado já constitui erro per $\operatorname{se}^{70}$ Em conseqüiência, a classificação do ato administrativo como vinculado ou discricionário, se não-equivocada, é de todo inócua. A atividade administrativa desenvolve-se com maior ou menor grau de discricionariedade, conforme o caso. Sua fragmentação em atos individuais perde sentido, na medida em que todos os atos administrativos seriam, de certa forma e em certa medida, vinculados e, igualmente, de certa forma e em certa medida, discricionários: sempre vinculados ao menos pela Constituição e pelas regras de competência administrativa e discricionários, conforme o grau de especificidade dos textos legais.

No entanto, o conceito de discricionariedade, não-ligado ao ato administrativo, mas à atividade administrativa, compreende a possibilidade de escolha, não totalmente independente e irresponsável, mas flexível e maleável que determina, sempre no caso concreto, a opção ótima para a consecução de determinados fins. ${ }^{71} \mathrm{Na}$

69. FORSTHOFF, op. cit., p. 29 c s..

70. GORDILlO, Augustin, El Acto Administrativo, 2a cd., Bucnos Aircs, Abeledo-Pcrrot, 1969, p. 31: "En consecuência, la búsqueda de una defnición de acto administrativo no puede existir (...) Nuestra investigación, pues, tiene por contenido el estudio del complejo total de la actividad administrativa". Também CIRNE LIMA, Ruy, Principios de Direito Administrativo, 5a cd., São Paulo, Revista dos Tribunais, 1982, p. 85: "A administração pública é atividade que merece, como conjunto, o reconhecimento e a proteção do direito para os fins que a governam"

71. BANDEIRA DE MELLO, Cclso Antônio, Discricionariedaule e Controle Judicial, 2a cd., Sào Paulo, Malhciros, p. 48: "Discricionariedade, portanto, é a margem de liberdade que remanesça ao administrador para eleger, segundo critérios consistentes de razoabilidade, um. dentre pelo menos dois componentes cabiveis, perante cada caso concreto, a fim de cumprir o dever de adotar a solução mais adequada à satisfação da finalidade legal". 
verdade, a discricionariedade aparece muito mais como um dever que um poder, pois é simples instrumento para a realização de fins postos. A discricionariedade é uma "liberdade vinculada", ${ }^{72}$ pois não implica atos discricionários ou vinculados, mas uma atividade administrativa apenas em certa medida discricionária e sempre minimamente vinculada. E assim devem ser compreendidas as políticas públicas, não como uma categoria jurídica própria do Direito Administrativo - como atos administrativos discricionários - mas, sim, enquanto atividade administrativa constitucionalmente orientada e, como tal, imbricada em todo o ordenamento jurídico, com graus de discricionariedade e vinculação somente identificáveis no caso concreto.

Em verdade, a escusa ao controle jurídico de políticas públicas constitui verdadeira afronta ao Estado de Direito, na medida em que exclui a possibilidade de apreciação de determinados atos que, em quaisquer circunstâncias, têm de estar submetidos à Constituição: "De antemão, o conceito de discricionariedade não constitui qualquer impedimento ou limitação ao controlo jurisdicional. A discricionariedade é, como já referimos, mais uma justificação para o não-controlo do que uma possibilidade de conduta do administrador" ${ }^{73}$ Destarte, combater o controle juridico de políticas públicas argumentando-se pela eliminação da discricionariedade administrativa implica verdadeiro escape às responsabilidades constitucionais impostas à administração pública.

\section{Conclusões}

Tendo em vista os objetivos pretendidos, a conclusão que se pode oferecer, à luz do disparate instaurado entre a promulgação da Constituição Federal e nossa praxis constitucional hodierna, não pode ser de modo algum otimista.

De fato, a reforma que se pretendeu esboçar nem pode ser imaginada a curto prazo em nosso País. Buscou-se apenas elocubrar uma hipótese de adequaçã̃o metodológica do Poder Judiciário brasileiro ao nosso diploma constitucional, de maneira racional, controlada e consciente, rompendo com a serindipidade jurisdicional que impede que a Jurisprudência nacional seja sólida e consistente.

Com efeito, essa proposta de reforma depende de profundas mudanças políticas e institucionais e, dentre elas, a mais importante é exatamente a formação dos juristas brasileiros. De fato, os cursos jurídicos brasileiros não promovem a formação teórica necessária para operar-se a metódica estruturante do Direito, sendo mantidos ainda em ortodoxos parâmetros positivistas e direcionados apenas para o mercado de trabalho. A formação do jurista, enquanto cientista social, enquanto Rechtsarbeiter autêntico, demanda formação multidisciplinar que traga a lume o debate político e social, bem como desenvolva a capacidade de reflexão metodológica no que diz respeito ao modo de concretizar-se o Direito.

72. SOUZA, António Francisco dc, A Discricionariẹdade Administrativa, Lisboa, Danúbio, 1987, p. 67. 73. SOUZA, op. cit., p. 62. 
Ficam, portanto, duas conclusões: de um lado, a otimista constatação de que há, efetivamente, uma via para reformar o Poder Judiciário de modo a implementar o controle jurídico de políticas públicas como condição essencial para a efetivação dos direitos sociais, econômicos e culturais no Brasil, sendo tal via sustentada metodologicamente pela metódica estruturante do Direito; e, de outro lado e a despeito de sua viabilidade hipotética, fica um frustrante e cético descrédito, pois à luz da vida política e constitucional brasileira hodierna e tendo em vista as profundas mudanças exigidas para implementar o controle jurídico de políticas públicas, a proposta de reforma do Poder Judiciário aqui apresentada está efetivamente muito distante de qualquer chance de efetiva implementação - pelo menos, por enquanto.

\section{Referências Bibliográficas Elementares}

BANDEIRA DE MELLO, Discricionariedade e Controle Judicial, 2" ed., São Paulo, Malheiros, 1998.

BERLIN, Isaiah, Quatro Ensaios sobre a Liberdade, trad. Wamberto Hudson Ferreira, Brasília, Universidade de Brasília, 1981.

CANARIS, Claus-Wilhelm, Pensamento Sistemático e Conceito de Sistema na Ciência do Direito, $2^{a}$ ed., trad. António Menezes Cordeiro, Lisboa, Fundação Calouste Gulbenkian, 1996.

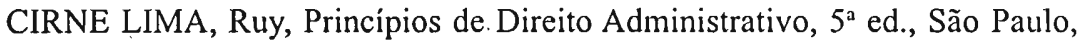
Revista dos Tribunais, 1982.

CANOTILHO, José Joaquim Gomes, Direito Constitucional e Teoria da Constituição, 2a ed., Coimbra, Livraria Almedina, 1998.

COMPARATO, Fábio Konder, "A Organização Constitucional da Função Planejadora" in Revista Trimestral de Direito Público, n. ${ }^{\circ}$ 8, São Paulo, 1994.

COMPARATO, Fábio Konder, "Ensaio sobre o Juízo de Constitucionalidade de Políticas Públicas", in Estudos em Homenagem a Geraldo Ataliba, BANDEIRA DE MELLO, Celso Antônio (org.), São Paulo, Malheịros, 1997.

CONSTANT, Benjamin, Da Liberdade dos Antigos Comparada à Liberdade dos Modernos, trad. Loura Silveira, s. local, s. data.

EHRLICH, Eugen, Fundamentos de Sociologia do Direito, trad. René Ernani Gertz, Brasília, Universidade de Brasília, 1986.

FERRAZ JR., Tércio Sampaio, "O Judiciário frente à Divisão dos Poderes: um princípio em decadência?", in Revista Trimestral de Direito Público, São Paulo, n. 9, 1995.

FORSTHOFF, Ernst, "Concetto e Natura dello Stato Sociale di Diritto", in Stato di Diritto in Transformazione, trad. Carlo Amirante, Milano, Giuffrè, 1973.

GADAMER, Hans-Georg, Verdade e Método: traços fundamentais de uma hermenêutica filosófica, trad. Flávio Paulo Meurer, Petrópolis, Vozes, 1997. 
GORDILLO, Augustin, El Acto Administrativo, $2^{\mathrm{a}}$ ed., Buenos Aires, AbeledoPerrot, 1969.

HABERMAS, Jürgen, "Law as Medium and Law as Institution", in TEUBNER, Gunther (org.), Dilemmas of Law in the Welfare State, Berlin/New York, European University Institute, 1985.

HADDAD, Fernando, "Economia Política da Desjuridificação", manuscrito não publicado e fornecido pelo autor.

HEGEL, Georg Wilhelm Friedrich, Enciclopédia das Ciências Filosóficas em Epitome, v. 1, trad. Artur Morão, Lisboa, Edições 70, 1988.

HEIDEGGER, Martin, Ser e Tempo, 2 ed., v. 1, trad. Márcia de Sá Cavalcanti, Petrópolis, Vozes, 1988.

HESSE, Konrad, "La Fuerza Normativa de la Constitución", in Escritos de Derecho Constitucional, trad. Pedro Cruz Villalon, Madrid, Centro de Estudios Constitucionales, 1992.

HOBSBAWN, Eric J., A Era das Revoluções, $10^{a}$ ed., trad. Maria Tereza Lopes Teixeira e Marcos Penchel, Rio de Janeiro, Paz e Terra, 1977.

KELSEN, Hans, Teoria Pura do Direito, $6^{\mathrm{a}}$ ed., trad. João Baptista Machado, Coimbra, Armenio Amado Editora, 1984.

KRIELE, Martin, Introdución a la Teoría del Estado: fundamentos históricos de la legitimidad del Estado Constitucional Democrático, trad. Eugênio Bulygin, Buenos Aires, Depalma, 1980.

LARENZ, Karl, Metodologia da Ciência do Direito, 6" ed., trad. José Lamego, Lisboa, Fundação Colouste Gulbenkian, 1997

LASSALE, Ferdinand, ¿Que es una Constitución? trad. W. Roces, Buenos Aires, Siglo Veinte, 1946.

LOEWENSTEIN, Karl, Teoria de la Constitución, $2^{\mathrm{a}}$ ed., trad. Alfredo Gallego Anabitarte, Barcelona, Ediciones Ariel, 1970.

MARSHALL, T. H., Cidadania, Classe Social e "Status", trad. Meton Porto Gadelha, Rio de Janeiro, Zahar Editores, 1967.

MONTESQUIEU, Charles de Secondat, Barão de, O Espirito das Leis, trad. Cristina Murachco, São Paulo, Martins Fontes, 1993.

MÜLLER, Friedrich, Direito, Linguagem, Violência. Elementos de uma Teoria Constitucional, v. 1, trad. Peter Neumann, Porto Alegre, Sergio Antonio Fabris, 1995.

MÜLLER, Friedrich, Discours sur la Méthode Juridique, $5^{\text {a }}$ ed., trad. Olivier Jouanjan, Paris, Presses Universitaires de France, 1996.

MÜLLER, Métodos de Trabalho do Direito Constitucional, $2^{2}$ ed., trad. Peter Naumann, São Paulo, Malheiros, 2000.

QUEIROZ, Cristina M.M., Os Actos Politicos no Estado de Direito: o problema do controle juridico do poder, Coimbra, Livraria Almedina, 1990. 
SARTORI, Giovanni, Teoria Democrática, trad. Francisco M. da Rocha Filho e Oswaldo Blois, Rio de Janeiro, Fundo de Cultura, 1965.

VIEHWEG, Theodor, Tópica e Jurisprudência; 5" ed., trad. Tércio Sampaio Ferraz Jr., Brasília, Universidade de Brasília e Ministério da Justiça (co-edição), 1979. 